


\section{Scientific analysis of the status of designated Natura 2000 areas and the protection of nitrogen-sensitive species and habitats}

Dutch contribution

A.M. Schmidt and R.A. Smidt 
A.M. Schmidt and R.A. Smidt, 2018. Scientific analysis of the status of designated Natura 2000 areas and the protection of nitrogen-sensitive species and habitats; Dutch contribution. Wageningen, Wageningen Environmental Research, Report 2880. 36 pp.; 10 fig.; 6 tab.; 8 ref.

The designation of Natura 2000 sites in the Netherlands took longer than expected. At present, 159 of 160 identified sites have been designated as Natura 2000 sites, and their management plans are currently being developed. About $60 \%$ of the land area in the Netherlands is used for agriculture, which puts significant pressure on the Natura 2000 network, particularly in terms of nitrogen inputs. The Dutch Integrated Approach to Nitrogen (PAS) aims to meet conservation objectives while facilitating economic development around the Natura 2000 sites within strict environmental limits. Nitrogen-sensitive Natura 2000 sites (118 of the 160) were identified by the presence of the nitrogensensitive habitats of species or habitat types (Annex I of the Habitats Directive). The critical load of nitrogen input (combined $\mathrm{NHy}$ and NOx) was calculated for each area based on the abiotic nutrient requirements of these habitats. For the purpose of the PAS, a specific monitoring programme is being developed.

Keywords: Nitrogen regulation, Natura 2000, habitat types, nitrogen input, agriculture, conservation

The pdf file is free of charge and can be downloaded at https://doi.org/10.18174/447946 or via the website www.wur.nl/environmental-research (scroll down to Publications - Wageningen Environmental Research reports). Wageningen Environmental Research does not deliver printed versions of the Wageningen Environmental Research reports.

2018 Wageningen Environmental Research (an institute under the auspices of the Stichting Wageningen Research), P.O. Box 47,6700 AA Wageningen, The Netherlands, T +31 (0)317 4807 00, www.wur.nl/environmental-research. Wageningen Environmental Research is part of Wageningen University \& Research.

- Acquisition, duplication and transmission of this publication is permitted with clear acknowledgement of the source.

- Acquisition, duplication and transmission is not permitted for commercial purposes and/or monetary gain.

- Acquisition, duplication and transmission is not permitted of any parts of this publication for which the copyrights clearly rest with other parties and/or are reserved.

Wageningen Environmental Research assumes no liability for any losses resulting from the use of the research results or recommendations in this report.

Wageningen Environmental Research Report 2880 | ISSN 1566-7197 


\section{Contents}

$\begin{array}{ll}\text { Summary } & 5\end{array}$

1

$\begin{array}{ll}\text { Introduction } & 7\end{array}$

$\begin{array}{lll}1.1 & \text { Background } & 7\end{array}$

$\begin{array}{lll}1.2 & \text { Objectives } & 7\end{array}$

$\begin{array}{lll}1.3 & \text { Approach } & 7\end{array}$

$\begin{array}{lll}1.4 & \text { Overview } & 7\end{array}$

2.1 Special Areas of Conservation (land and sea), their sizes, and the number of habitat types they contain

2.2 Biogeographical distribution of Natura 2000 habitat types 8

2.3 Percentage of land covered by Natura 2000 areas 8

2.4 Land area covered by SACs $\quad 9$

2.5 Land area covered by SPAs 9

2.6 Quantity of natural non-cultivated areas 9

2.7 Annex I habitat types and Annex II species present in Natura 2000
designated sites

$\begin{array}{lll}2.8 & \text { The Natura } 2000 \text { designation process } & 10\end{array}$

2.9 The involvement of NGOs in the designation process $\quad 10$

2.10 Areas of intensive agricultural production within the Natura 2000 sites $\quad 11$

2.11 Intensive agricultural production within buffer zones surrounding the
Natura 2000 sites

2.12 Arable, pastoral, or mixed agriculture within buffer zones surrounding the Natura 2000 sites

The state of the Natura 2000 areas and efforts to improve them

3.1 Monitoring and assessment of the state of the Natura 2000 areas

3.1.1 Monitoring species and habitats at the national, regional and/or site level

3.1.2 Monitoring for the purpose of the Natura 2000 management plans

3.1.3 Monitoring for the purpose of the Dutch Integrated Approach to Nitrogen (PAS)

3.2 Trends in the conservation status of terrestrial habitat types

3.3 Pressures giving rise to the changes in (terrestrial) habitat types

3.4.1 Identification of measures for the Natura 2000 management plans 19

3.4.2 Identification of measures for the PAS 19

3.5 Nitrogen / ammonia sensitivity assessment 19

3.6 Implementation of the national monitoring programmes 20

3.7 Implementation of the Natura 2000 management plans 20

3.8 Monitoring and assessing the (biological) effects of the Natura 2000 management plans (period 2004-2015) 
Annex $1 \quad$ Natura 2000 areas in the Netherlands

Annex 2 Nitrogen-sensitive Special Areas of Conservation in the Netherlands

Annex 3 Annex I of the Habitats Directive: Habitat types

29

Annex 4 Species of Annex II of the Habitat Directive

31

Annex 5 Percentage of Natura 2000 areas subjected to intensive agriculture 


\section{Summary}

The Natura 2000 network in the Netherlands consists of 160 protected sites. At present, 159 of these sites have been officially designated by the Dutch government; however, the designation process took longer than expected and the development of management plans for these Natura 2000 sites is still ongoing.

About $60 \%$ of the land area in the Netherlands is used for agriculture. The Natura 2000 network protects about $10 \%$ of the country's terrestrial areas, of which approximately $11 \%$ is agricultural land. A further $18 \%$ of the 1-2-km buffer zones surrounding the Natura 2000 sites comprises agricultural land, which puts significant pressure on the protected areas, particularly in terms of nitrogen input.

The Dutch Integrated Approach to Nitrogen (in Dutch: Programma Aanpak Stikstof (PAS)) is a national plan that combines measures to reduce the levels of nitrogen emission with ecological restoration measures in the Natura 2000 areas, leaving room for economic development. The aim of the PAS is to ensure that conservation objectives are achieved while facilitating further economic development around Natura 2000 areas, within strict environmental limits. In total, 118 of the 160 Natura 2000 areas have been identified as nitrogen-sensitive areas based on the presence of at least one nitrogensensitive habitat type (Annex I of the Habitats Directive) or the nitrogen-sensitive habitat for species. Measures have been identified to address both the sources of nitrogen deposition and restore the status (quality) of these nitrogen-sensitive areas.

The identification of habitats of nitrogen-sensitive species (not part of Annex I of the Habitats Directive) and habitat types (Annex I) is based on the abiotic requirements of these habitats. The combined critical loads of $\mathrm{NHy}$ and NOx were calculated for each region based on their nitrogen requirements. Nitrogen deposition in the Natura 2000 areas was calculated based on the nitrogen sources (different types of sources), meteorological conditions, surface roughness and land cover, utilizing a special tool, 'AERIUS' (see https://www.aerius.nl/en), developed for this purpose.

It is difficult to conclude the biological effects of the Natura 2000 management plans from monitoring data collected in the period 2004-2015, particularly in terms of determining how they may have led to the observed trends in, for example, the population sizes of species. During this period and over the last two years, standardised methods were developed to acquire the necessary data for the quantitative and qualitative assessment of these habitats.

A monitoring programme is being developed for the purposes of the PAS, which consists of:

1. Monitoring the presence, size and quality of nitrogen-sensitive habitat types.

2. Monitoring the habitats of nitrogen-sensitive species.

3. Monitoring using 'field visits'; spot checks of relevant aspects of all Natura 2000 areas within the PAS framework.

4. Monitoring the progress of restoration measures.

5. Monitoring process indicators; the systematic monitoring of the effects of restoration measures. 


\section{Introduction}

\section{$1.1 \quad$ Background}

The Department of Food and Economics (IFRO) at the University of Copenhagen asked Wageningen Environmental Research (WENR) to participate in a scientific analysis of the status of designated Natura 2000 areas and the protection of nitrogen-sensitive species and habitats.

\subsection{Objectives}

The objectives of this research were to provide insights into the Nature 2000 designation process, the state of the protected ecosystems, and the efforts being made to protect nitrogen-sensitive habitats (specifically for measures to reduce ammonia emissions from livestock) by different EU member states (in this case the Netherlands). Research questions were posed on these two topics by IFRO.

\subsection{Approach}

Geographic information system (GIS) analyses were performed and existing policy documents, scientific reports and articles were consulted to answer the research questions posed by IFRO.

\subsection{Overview}

In chapter 2, the research questions regarding the Nature 2000 designation process in the Netherlands are addressed. In chapter 3, the state of the protected ecosystems and the efforts being made to improve them in the Netherlands are described. 


\section{The national designation of Natura 2000 areas}

\subsection{Special Areas of Conservation (land and sea), their sizes, and the number of habitat types they contain}

The Netherlands has designated 137 Special Areas of Conservation (SACs) and 77 Special Protection Areas (SPAs; Table 1). One Site of Community Importance (SCI), 'Krammerak-Volkerak', has not yet been assigned. Due to large overlap of the SACs and SPAs, they comprise a total of 160 Natura 2000 areas (Appendix 1), including 20 sites in which the borders of the SACs and SPAs precisely overlap (site type C in the Standard Data Form; Table 1).

Table 1 The number of Special Protection Areas (SPAs), Sites of Community Importance (SCIs) and/or Special Areas of Conservation (SACS) in the Netherlands (source: Standard Data Forms, version $10^{\text {th }}$ October 2016).

\begin{tabular}{lll} 
Site Type & Protection status & Number of sites \\
A & SPA & 57 \\
\hline B & SCI and/or SAC & 118 \\
\hline C & Combined SPA and SAC & 20 \\
\hline
\end{tabular}

The SACs vary in size between 15 and 473,500 ha, with an average size of 11,052 ha; however, most Natura 2000 areas are relatively small (< 5000 ha; Appendix 2). The number of habitat types (Annex I) present at each site varies from 0 to 9 (Appendix 2).

\subsection{Biogeographical distribution of Natura 2000 habitat types}

There are two biogeographical regions in the Netherlands; the Atlantic region and the Marine Atlantic region. All marine habitat types (the 1100 series), which comprise a total of 1,128,285.6 ha within the Natura 2000 sites, are located in the Marine Atlantic region of the country. All terrestrial and aquatic (inland waters) habitat types are located in the Atlantic region, with a total of 110,113.91 ha contained within the Natura 2000 sites.

\subsection{Percentage of land covered by Natura 2000 areas}

A total of $10 \%$ of the land in the Netherlands is contained within Natura 2000 areas $(345,457.3$ ha). This percentage was calculated using a GIS analysis, in which the borders of the Natura 2000 network were overlaid onto the Land Use Database of the Netherlands. Only the coastal waters (sea), estuaries and closed sea inlets were excluded in this analysis (Figure 1); inland waters such as rivers and lakes were included. 


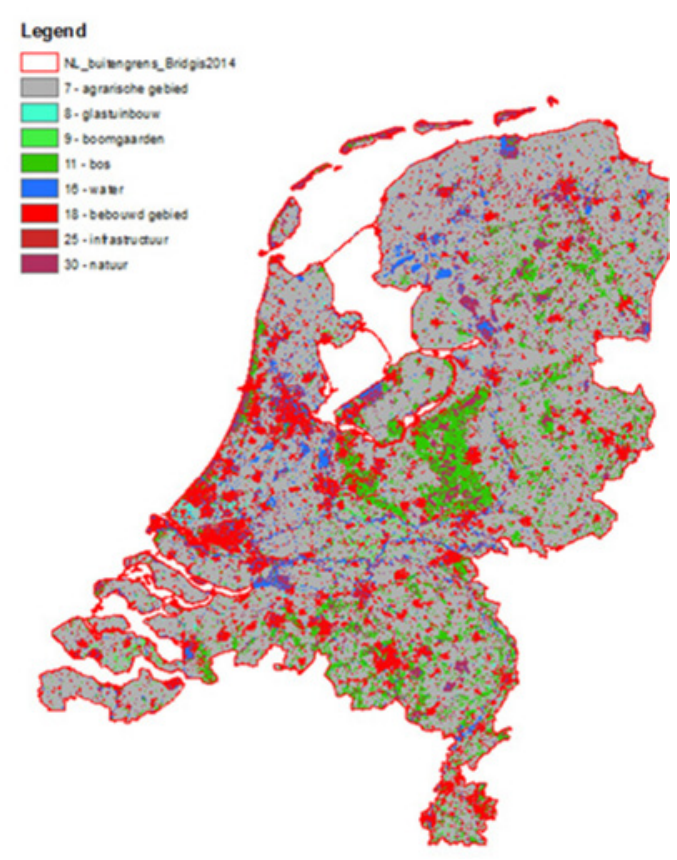

Figure 1 Land use in the Netherlands. Source: The Land Use Database of the Netherlands: the land surface (http://www.wur.nl/en/Expertise-Services/Research-Institutes/EnvironmentalResearch/Facilities-Products/Land-use-database-of-the-Netherlands.htm).

\subsection{Land area covered by SACs}

SACs cover $8.2 \%(289,031.9$ ha $)$ of the total land area in the Netherlands.

\subsection{Land area covered by SPAs}

SPAs cover $7.5 \%(264,032.4 \mathrm{ha})$ of the total land area in the Netherlands, which is a little less than the area covered by the SACs (section 2.4 ).

\subsection{Quantity of natural non-cultivated areas}

Natural non-cultivated areas (forest and other natural areas) comprise $18 \%$ of the land surface in the Netherlands (Table 2), while most of the land surface in the country $(60 \%)$ is used for agricultural purposes. This percentage was calculated using a GIS analysis of the agricultural land use classes listed in the Land Use Database of the Netherlands.

Table 2 Land use in the Netherlands. Source: The Land Use Database of the Netherlands: the land surface.

\begin{tabular}{ll} 
Land cover category & Percentage of land \\
Agriculture & $60 \%$ \\
\hline Greenhouse cultivation & $<1 \%$ \\
\hline Orchards & $1 \%$ \\
\hline Forest & $10 \%$ \\
\hline Inland waters & $5 \%$ \\
\hline Built-up area & $14 \%$ \\
\hline Infrastructure & $2 \%$ \\
\hline Nature & $8 \%$ \\
\hline
\end{tabular}




\subsection{Annex I habitat types and Annex II species present in Natura 2000 designated sites}

A total of 52 Annex I habitat types (Appendix 3) and 36 Annex II species (Appendix 4) were present in the designated Natura 2000 sites (SACs) in the Netherlands.

\subsection{The Natura 2000 designation process}

The Natura 2000 areas are designated by the Ministry for Economic Affairs, Agriculture and Innovation (previously the Ministry of Agriculture, Nature and Food Security). Before the Natura 2000 areas can be designated under the Dutch Nature Conservation Act, the draft designation decrees are deposited for public inspection under the Dutch General Administrative Law Act.

The EU Birds Directive came into force in 1980. Most of the SPAs were designated in 2000, following a 1989 European Court of Justice ruling that the Netherlands had not complied with their obligations to designate SPAs (described by Backes and Keessen, 2017). The EU Habitats Directive was enacted in 1994; however, the designation process of SACs was again delayed. In 2004, a list of SCIs was published, the vast majority of which (137 of 138 ) have now been designated as SACs. This designation process took about ten years (Figure 2).

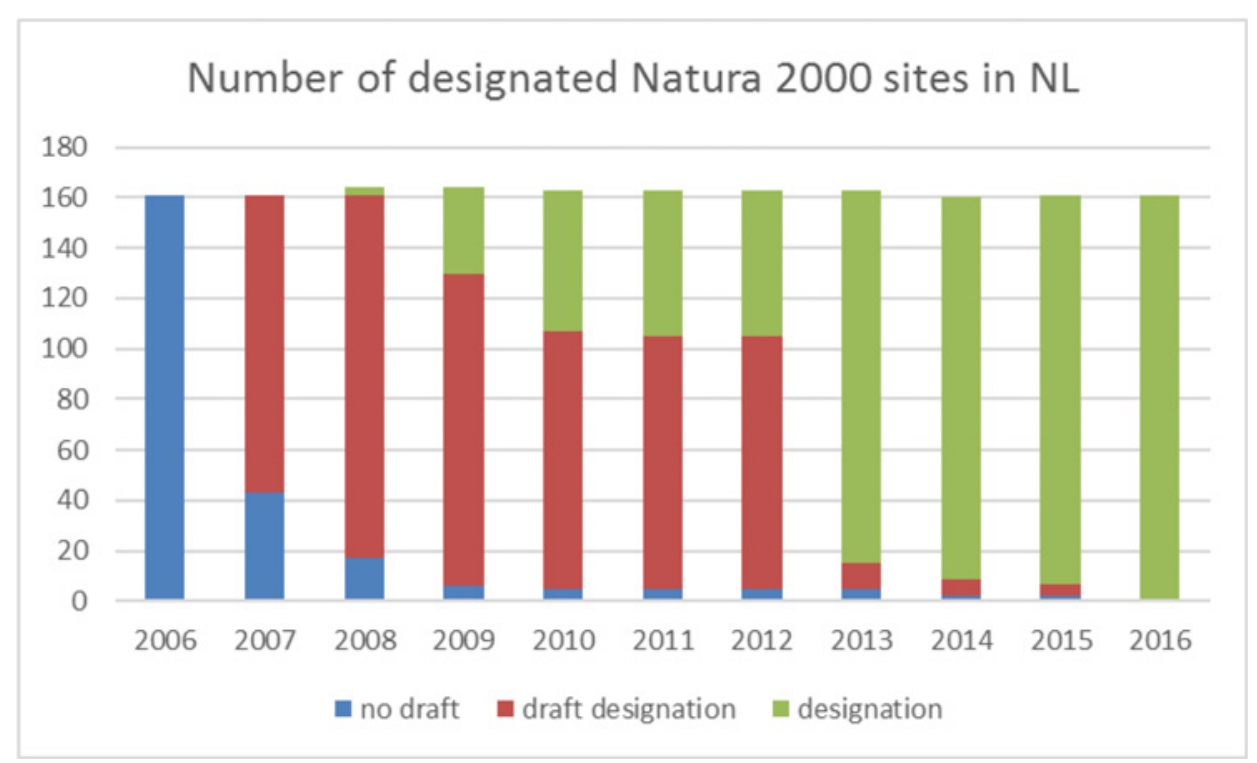

Figure 2 The designation process of Natura 2000 areas between 2006 and 2016. Before Natura 2000 areas are designated, draft designation decrees must be deposited for public inspection.

\subsection{The involvement of NGOs in the designation process}

Non-governmental organisations (NGOs) have been strongly involved in the Natura 2000 designation process, specifically in identifying the area's most important for the conservation of species. The designation of the Natura 2000 areas is, to a large extent, based on the information and expertise provided by NGOs, nature conservation organisations, and research institutes.

The designation process of both the SPAs and the SACs took a long time (section 2.8). Several changes have been made to the boundaries of the Natura 2000 areas, as well to the conservation objectives for these regions. The latter are often based on improved information and knowledge of the Natura 2000 


\subsection{Areas of intensive agricultural production within the Natura 2000 sites}

A GIS analysis using an overlay of the borders of the Natura 2000 network onto the Land Use Database of the Netherlands (see Figure 1) indicated that $11 \%$ of the land surface within the Natura 2000 network is used for agricultural purposes (Table 3). Permanent grasslands were included as agricultural areas for this analysis, as they are often managed intensively (e.g. fertilised and frequently mown).

Table 3 Land use in the Netherlands and the Natura 2000 network. Source: The Land Use Database of the Netherlands: the land surface.

\begin{tabular}{lcc}
$\begin{array}{l}\text { Land cover category } \\
\text { Agriculture }\end{array}$ & $\begin{array}{c}\text { Percentage of land in the } \\
\text { Netherlands }\end{array}$ & $\begin{array}{c}\text { Percentage of land covered by the Natura } \\
2000 \text { network }\end{array}$ \\
\hline Greenhouse cultivation & $60 \%$ & $11 \%$ \\
\hline Orchards & $1 \%$ & $<\%$ \\
\hline Forest & $10 \%$ & $32 \%$ \\
\hline Inland waters & $5 \%$ & $12 \%$ \\
\hline Built-up area & $14 \%$ & $1 \%$ \\
\hline Infrastructure & $2 \%$ & $0 \%$ \\
\hline Nature & $8 \%$ & $43 \%$ \\
\hline
\end{tabular}

A GIS analysis using the Land Parcel Identification System (in Dutch: Basisregistratie Percelen (BRP)) and the Geographic Information System for Agricultural Holdings (in Dutch: Geografisch Informatiesysteem Agrarische Bedrijven (GIAB)) demonstrated that $16 \%$ of the total land surface area of the Natura 2000 network is under intensive agricultural production (higher than the $11 \%$ estimate derived from the analysis using the Land Use Database). Again, the permanent grasslands were included in this analysis; however, if they were excluded, only $8 \%$ of the Natura 2000 network was considered to be under intensive agricultural production. The causes of the differences between the estimates generated using the Land Use Database and the BRP and GIAB have not been studied, but are likely related to differences in the definitions of land use categories and the information upon which the databases are built. The percentage of each Natura 2000 site (SACs and SPAs) under intensive agricultural production is listed in Appendix 5.

\subsection{Intensive agricultural production within buffer zones surrounding the Natura 2000 sites}

The total areas of land under intensive agricultural production in buffer zones of 100, 1000 or 2000 metres around the Natura 2000 sites were calculated using a GIS analysis of BRP and GIAB data (Table 4). 
Table 4 Intensive agricultural production (including and excluding permanent grasslands) in buffer zones of 100, 1000 or 2000 metres surrounding the Natura 2000 sites.

\begin{tabular}{llcc} 
Buffer zone & Area (ha) & Including permanent grasslands & Excluding permanent grasslands \\
$100 \mathrm{~m}$ & 91,071 & $32 \%$ & $16 \%$ \\
\hline $1000 \mathrm{~m}$ & 700,439 & $18 \%$ & $17 \%$ \\
\hline $2000 \mathrm{~m}$ & $1,313,281$ & $18 \%$ & $17 \%$
\end{tabular}

\subsection{Arable, pastoral, or mixed agriculture within buffer zones surrounding the Natura 2000 sites}

The number of hectares dedicated to arable, pastoral or mixed agriculture within 1000- or 2000-m buffer zones surrounding the Natura 2000 sites, calculated using a GIS analysis of BRP and GIAB data (Table 5).

Table 5 The number of hectares dedicated to arable, pastoral, or mixed agriculture in the 1000or 2000-m buffer zones surrounding the Natura 2000 sites.

\begin{tabular}{crrrrr} 
Buffer zone & Unknown & Arable & Pastoral & Mixed \\
$1000 \mathrm{~m}$ & $96,818 \mathrm{ha}$ & 63,054 ha & 117,140 ha & 11,171 ha & 288,182 ha \\
\hline $2000 \mathrm{~m}$ & $182,995 \mathrm{ha}$ & $121,416 \mathrm{ha}$ & 217,641 ha & 19,877 ha & 541,930 ha \\
\hline
\end{tabular}




\section{3 \\ The state of the Natura 2000 areas and efforts to improve them}

\subsection{Monitoring and assessment of the state of the Natura 2000 areas}

Several national and regional monitoring programmes provide data and information on the status and trends of species and/or habitats in the Netherlands, and their organisation is quite complex.

\subsubsection{Monitoring species and habitats at the national, regional and/or site level}

Fundamental differences exist between the approaches used to monitor species and habitats in the Netherlands (Table 6). Whereas species monitoring is, to a large extent, executed by volunteers and experts from NGOs, habitat monitoring is mainly performed by experts from nature conservation organisations or private companies.

Table 6 Differences between species and habitat monitoring approaches in the Netherlands.

\begin{tabular}{|c|c|c|}
\hline & Species & Habitats \\
\hline $\begin{array}{l}\text { Managing authority and } \\
\text { funders }\end{array}$ & $\begin{array}{l}\text { National government, regional authorities } \\
\text { and, to some extent, nature conservation } \\
\text { organisations }\end{array}$ & $\begin{array}{l}\text { Regional authorities, nature conservation } \\
\text { organisations and, to some extent, national } \\
\text { governments }\end{array}$ \\
\hline Executor (data collector) & $\begin{array}{l}\text { NGOs, volunteers and, to a lesser extent, } \\
\text { scientific institutes }\end{array}$ & $\begin{array}{l}\text { Nature conservation organisations, private } \\
\text { companies and, to a lesser extent, scientific } \\
\text { institutes }\end{array}$ \\
\hline Quality control & $\begin{array}{l}\text { The application of field protocols, validation } \\
\text { by the Central Bureau of Statistics }\end{array}$ & The application of field protocols \\
\hline $\begin{array}{l}\text { General approach / } \\
\text { organisation }\end{array}$ & $\begin{array}{l}\text { National perspective (top down): from } \\
\text { national scale to site scale }\end{array}$ & $\begin{array}{l}\text { Site perspective (bottom up): from site scale } \\
\text { to national scale }\end{array}$ \\
\hline Monitoring strategies & $\begin{array}{l}\text { National sampling schemes (statistically } \\
\text { robust) }\end{array}$ & Sequential mapping of sites \\
\hline
\end{tabular}

Species monitoring is organised from a national perspective (a top-down approach), partly because NGOs are organised at a national scale for each species group. The monitoring objectives and protocols are decided upon by national and regional governments in collaboration with the NGOs, within the context of the Network for Ecological Monitoring (in Dutch: Netwerk Ecologische Monitoring (NEM), see http://www.netwerkecologischemonitoring.nl/).

Habitat monitoring (in terms of vegetation, species composition and abiotic factors) is organised from a site perspective (a bottom-up approach), partly because nature conservation organisations are responsible for the management of a selection of sites (not necessarily Natura 2000 sites) distributed throughout the Netherlands. Most nature conservation organisations receive subsidies from the Dutch government to manage ecosystems (in Dutch: Subsidiestelsel Natuur en Landschapsbeheer (SNL), and within this context, agreements on monitoring objectives and protocols are made between the regional governments and the nature conservation organisations.

The techniques used for species and habitat monitoring are also different. Species are largely monitored with national sampling schemes, whereas habitat monitoring is based on the sequential mapping of the managed areas (organised at the site level). The Central Bureau of Statistics (CBS) 
plays an important role in species monitoring by validating the collected data and its statistical analysis; however, the role of the CBS in validating habitat monitoring has been limited.

\subsubsection{Monitoring for the purpose of the Natura 2000 management plans}

Regional authorities and the national government (the Ministry of Economic Affairs, the ministry of Infrastructure and Environment and the Ministry of Defence) are responsible for the monitoring and assessment of the state of species and habitats in the Natura 2000 sites, as well as the development of management plans for each location. The monitoring and assessment protocols for the Natura 2000 sites are still being developed. Agreements have been made between the regional authorities and the nature conservation organisations regarding the data to be collected for the purpose of Natura 2000, as well as for the management of ecosystems in general (not only for Natura 2000 purposes). These approaches were developed for use in the monitoring and assessment of 'nature quality' (in Dutch: natuurkwaliteit); however, they also concern the monitoring and assessment of 'ecosystem quality' by addressing ecosystem characteristics such as species composition (flora and fauna), structure and function.

\subsubsection{Monitoring for the purpose of the Dutch Integrated Approach to Nitrogen} (PAS)

A specific monitoring programme is being developed for use in the PAS, which consists of:

1. Monitoring the presence, size and quality of nitrogen-sensitive habitat types.

2. Monitoring the habitats of nitrogen-sensitive species.

3. Monitoring using 'field visits'; spot checks of relevant aspects of all Natura 2000 areas within the PAS framework.

4. Monitoring the progress of restoration measures.

5. Monitoring process indicators; the systematic monitoring of the effects of restoration measures.

\subsection{Trends in the conservation status of terrestrial habitat types}

The overall trends in the conservation status of the terrestrial habitat types in the Netherlands (46 in total) are presented in Figure 3. Standardised methods for monitoring and assessing the structure and function of these habitat types are under development, which means there is currently a lack of quality data for these factors. This makes it difficult to provide scientific evidence of changes in the conservation status of the habitat types.

\section{Trend in conservation status habitat types}

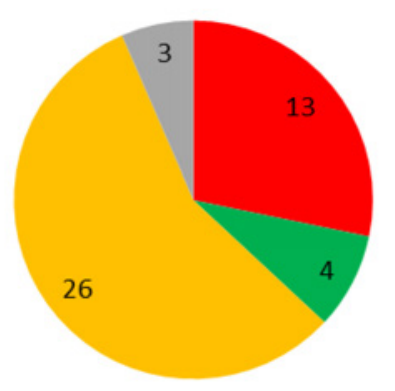

Figure 3 Trends in the conservation status of terrestrial habitat types for Natura 2000 sites in the Netherlands. Source: Report for Article 17 of the Habitats Directive (period 2007-2012). 


\subsection{Pressures giving rise to the changes in (terrestrial) habitat types}

Based on the information provided in the Standard Data Forms, it can be concluded that main pressures on Natura 2000 sites are agriculture, pollution, natural system modifications and abiotic and biotic processes (Figure 4).

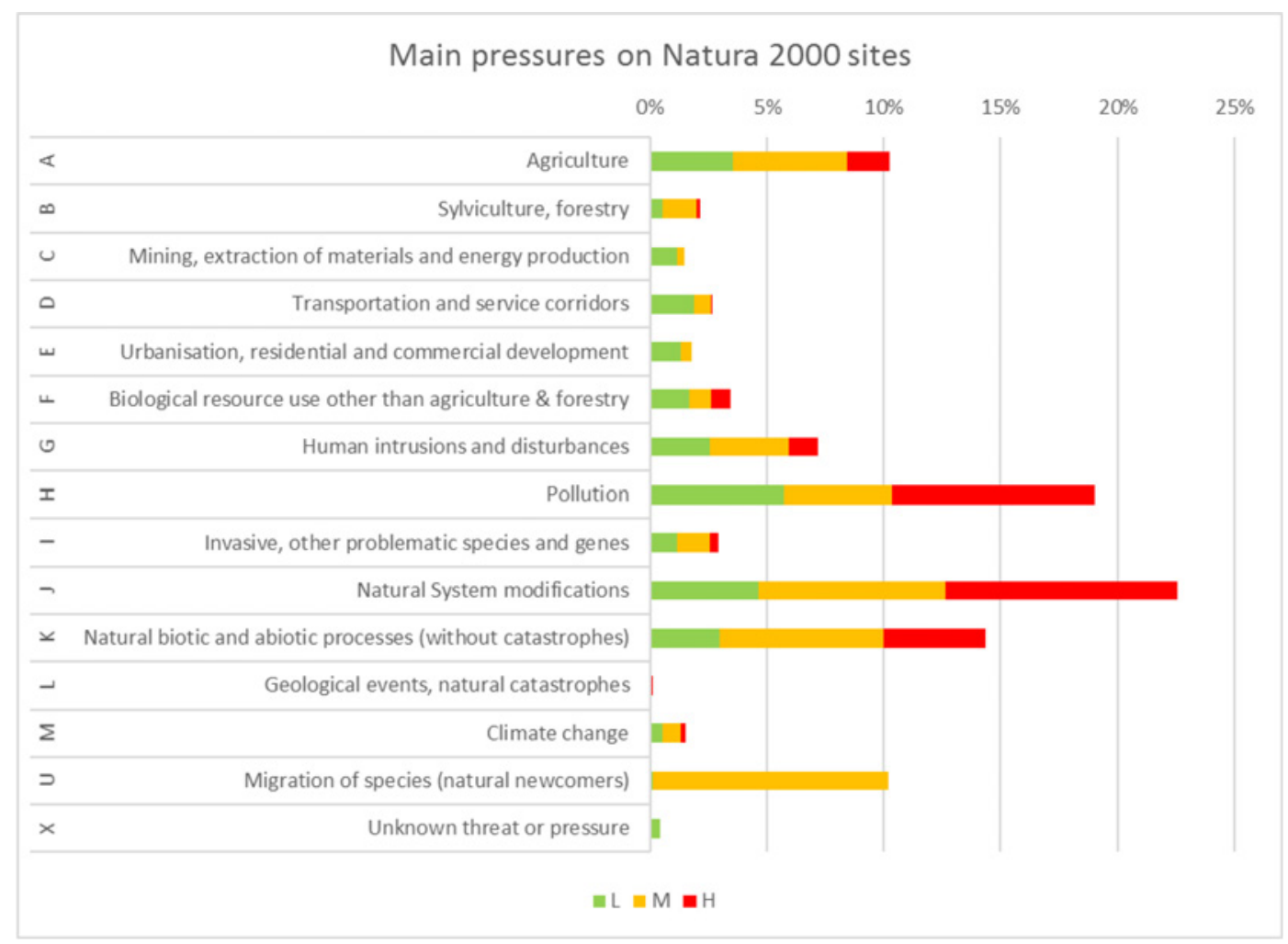

Figure 4 Main pressures on the Natura 2000 sites in the Netherlands, with low (L), medium (M) and high $(H)$ impacts (source: Standard Data Forms, version 10th October 2016). The percentages were calculated based on the relative number of sites with pressures belonging to a certain category (agriculture, forestry etc.).

By examining the agricultural pressures in more detail, the main issues are found to be agricultural intensification, the lack of properly performed land management measures (e.g. grazing, mowing etc.), and the use of biocides, hormones, chemicals and fertilisers (Figure 5). 


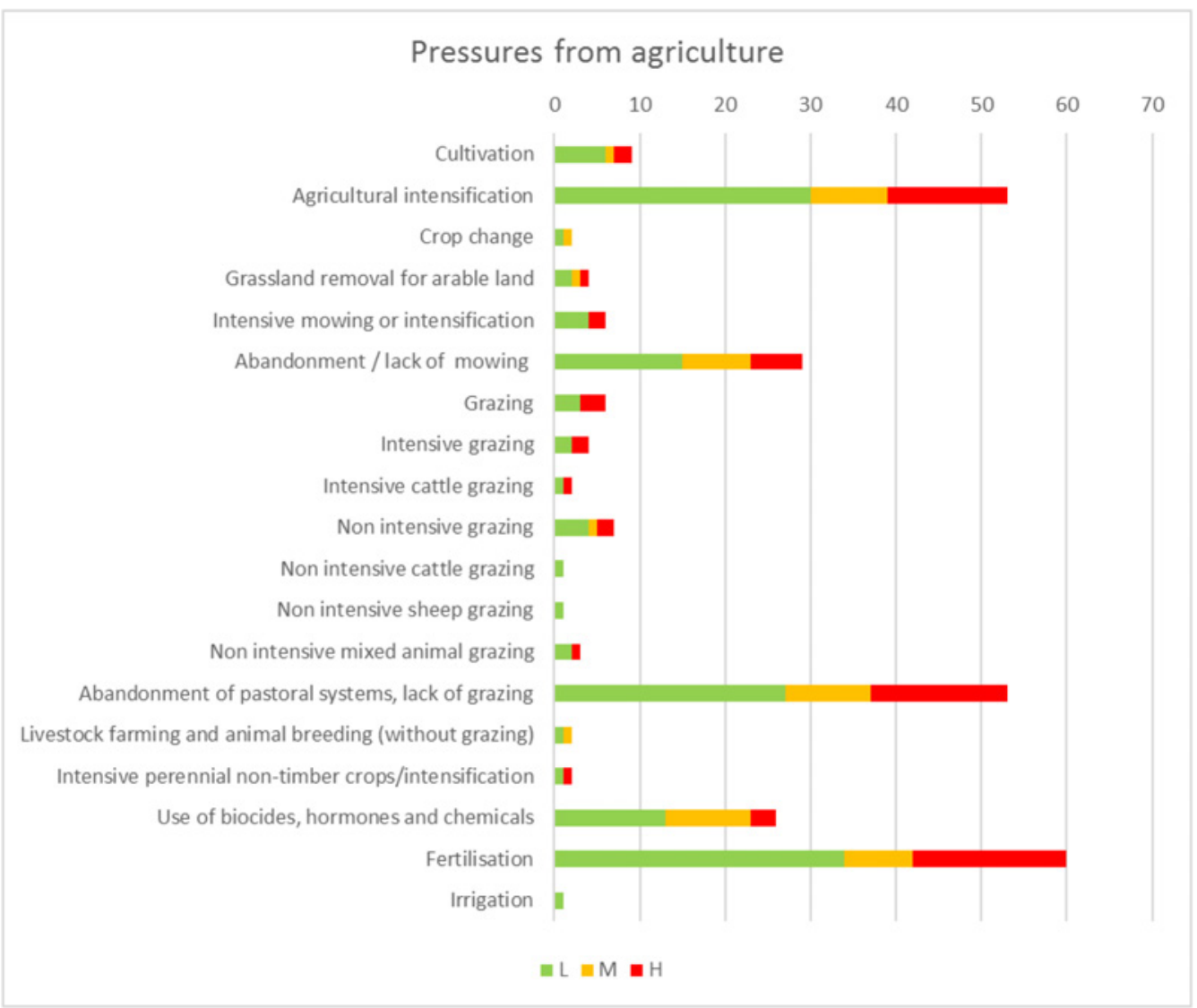

Figure 5 Pressure from agriculture on the Natura 2000 sites in the Netherlands. Number of sites under pressure from each subcategory (source: Standard Data Forms, version 10th October 2016). $L$, low impact; $M$, medium impact; $H$, high impact.

Nitrogen input, acid rain, ground water and surface water pollution are the most commonly occurring pressures under the main category 'Pollution' (Figure 6). Nitrogen input is mainly caused by the deposition of nitrogen-based fertilisers during agricultural activities.

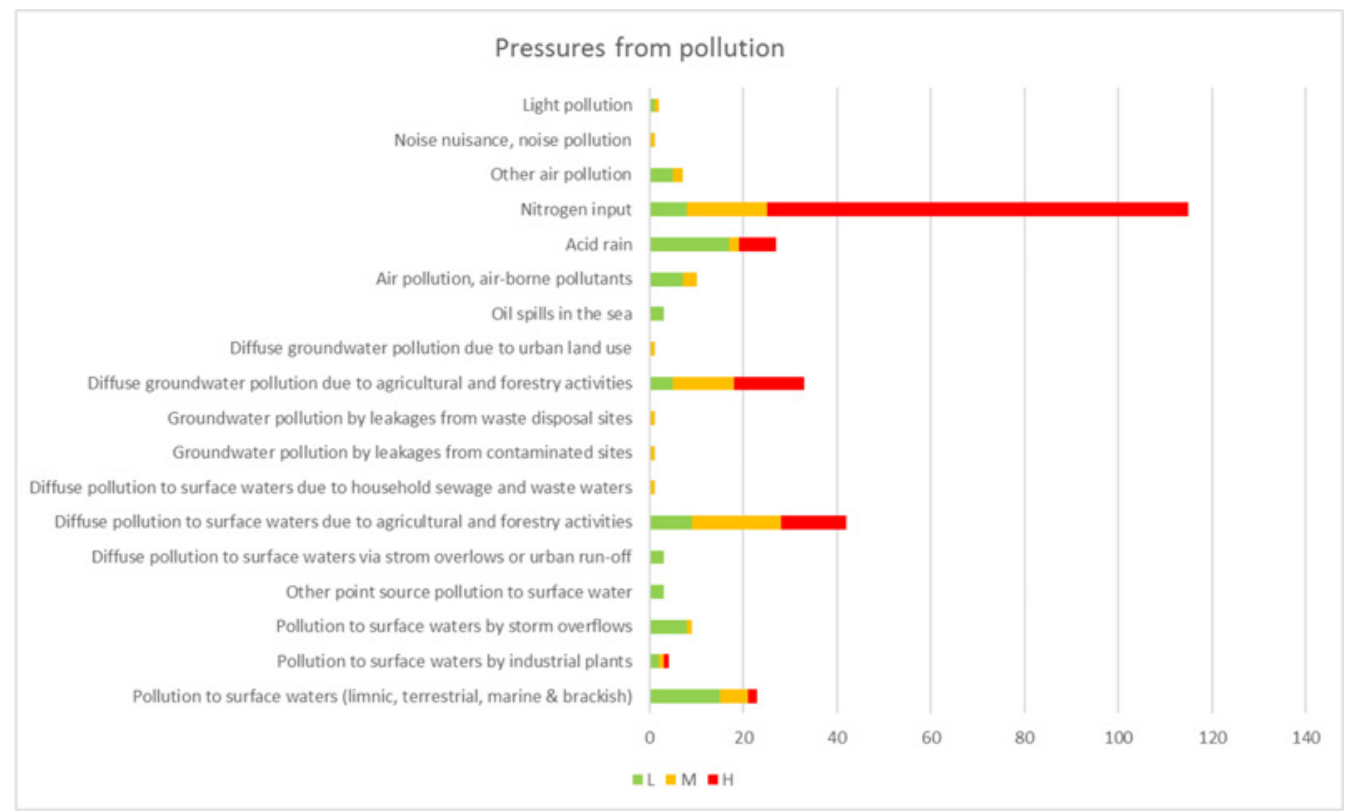

Figure 6 Pressures from the pollution of the Natura 2000 sites in the Netherlands. Number of sites under pressure for each subcategory (source: Standard Data Forms, version 10th October 2016). $L$, low impact; $M$, medium impact; $H$, high impact. 
The Netherlands Environmental Assessment Agency (in Dutch: Planbureau voor de Leefomgeving (PBL)) concluded that ammonia emissions from agriculture and horticulture declined by $65 \%$ between 1990 and 2015 (Figure 7). The emissions were not measured directly, but were calculated based on available information about the number of animals, nitrogen excretion, emission factors and so on. The sources of ammonia emissions (fertilisers, pastoralism, storage of manure etc.) were distinguished from one another in this analysis. The National Emission Model for Agriculture (Vonk et al., 2016) was used for these calculations.

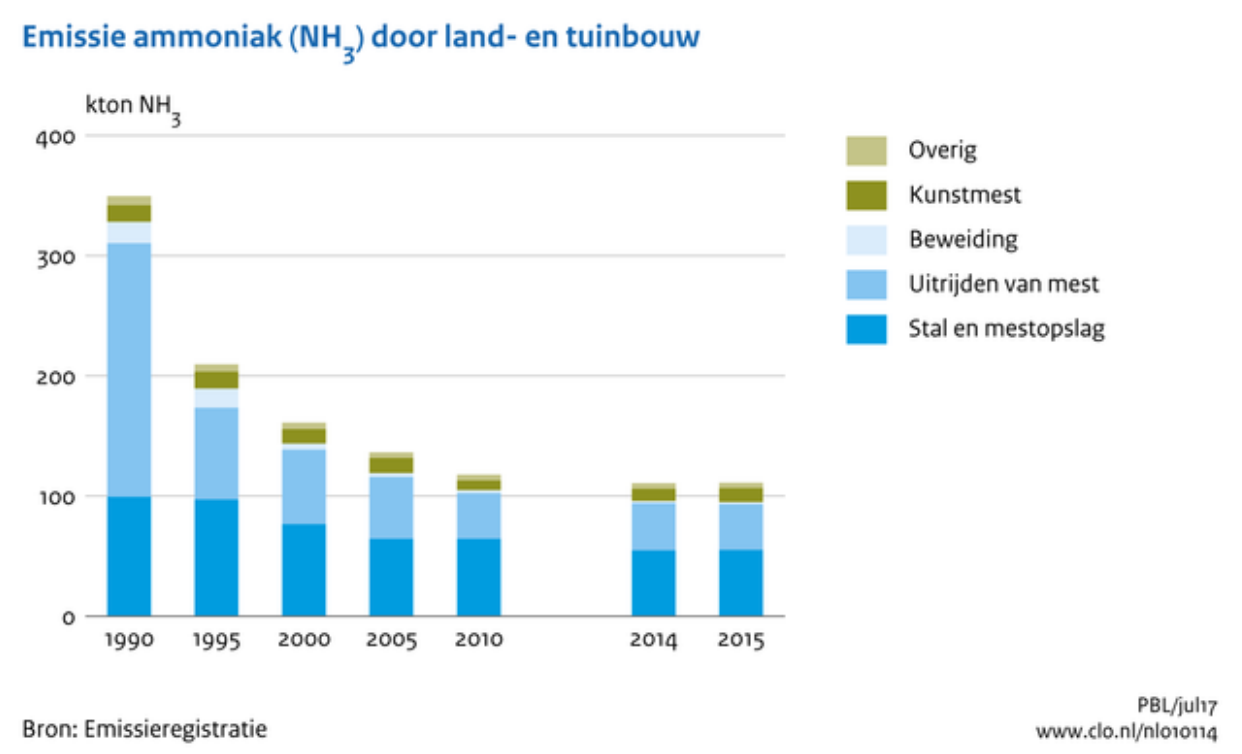

Figure 7 Ammonia emissions from agriculture and horticulture between 1990 and 2015. Source: www.clo.nl. overig: other; kunstmest: chemical fertilizer: beweiding: grazing: uitrijden mest: manure treatment; stal en mestopslag: stable and manure storage.

Although the pressures on the state of the Natura 2000 sites are decreasing (Figure 8), the level of nitrogen deposition in many of the natural areas in the Netherlands is still exceeding the threshold critical load (see Figure 9). 
Milieudruk op water en natuurgebieden
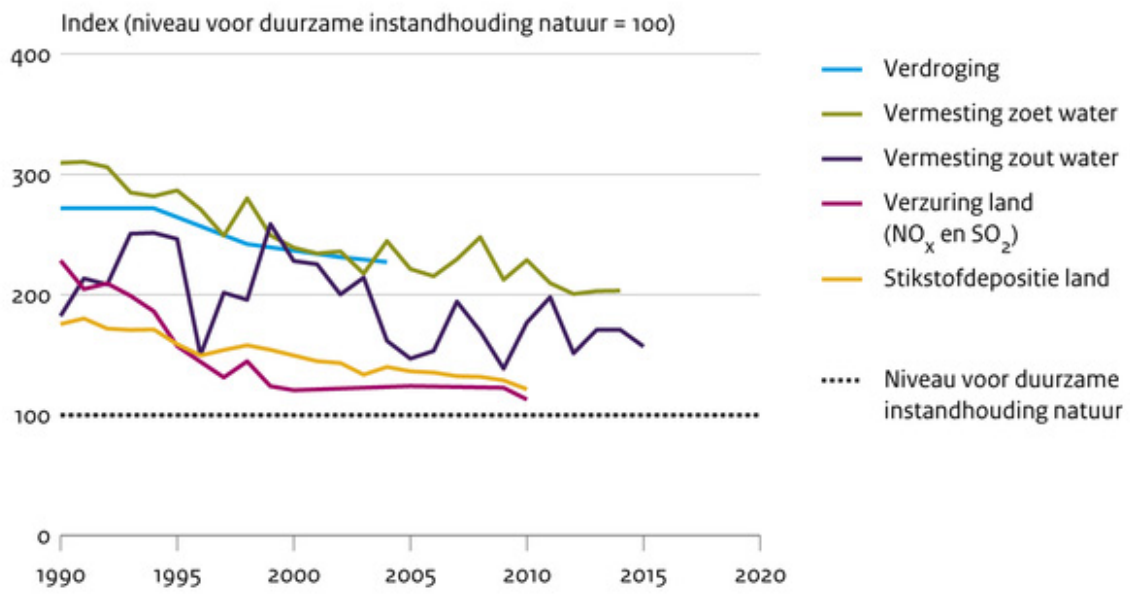

Bron: PBL

PBL/aug16
www.clo.nl/nl152205

Figure 8 Pressures of nitrogen pollution on aquatic systems and terrestrial habitats. verdroging: desiccation; vermesting: over-fertilisation; verzuring: acidification; stikstofdepositie: nitrogen deposition; zoet water: freshwater; zout water: saltwater. The dotted line (Index $=100$ ) reflects the maximum level for a favourable conservation status. Source: www.clo.nl.

Overschrijding kritische stikstofdepositie op natuur, 2009

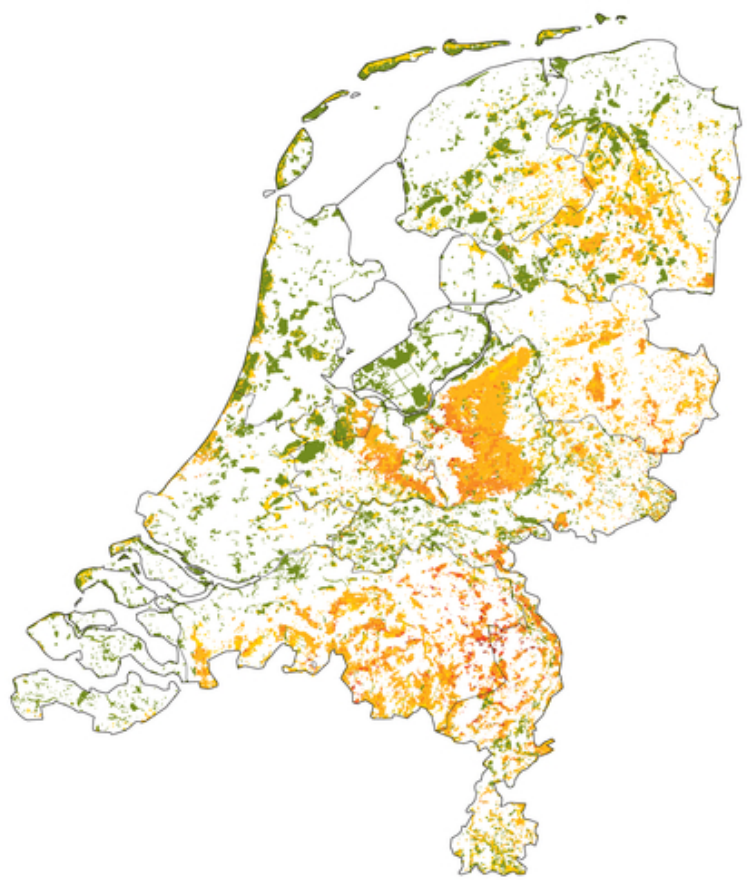

Mol N / ha per jaar

$\square-500$

प $500-1.000$

$1.000-1.500$

$1.500-2.000$

Meer dan 2.000

Geen overschrijding

Bron: PBL, GCN.

Figure $9 \quad$ Natural areas in the Netherlands where the critical nitrogen deposition levels are either exceeded (yellow to red) or not exceeded (green). Source: www.clo.nl. 


\subsection{Monitoring and assessment methods for the identification of actions/measures to be included in Natura 2000 management plans}

\subsubsection{Identification of measures for the Natura 2000 management plans}

The Ministry of Economic Affairs produced a guidance document and checklist for the national and regional authorities responsible for the Natura 2000 management plans (12 provinces and 3 ministries). The management plans should include a description of the main characteristics of the Natura 2000 area, an elaboration of the conservation objectives at the site level, and a description of the measures that are required to reach these objectives. There are specific sections on the measures needed to solve the pressures related to nitrogen (in Dutch: stikstofparagraaf) and water (in Dutch: waterparagraaf). The pressures related to nitrogen are addressed by the PAS (see next section). The pressures related to water are, to some extent, addressed within the context of the Water Framework Directive. Other types of nature conservation measures are addressed within the context of the SNL (see section 3.1). The Natura 2000 management plans therefore often refer to these programmes/instruments.

\subsubsection{Identification of measures for the PAS}

The PAS aims to reduce nitrogen deposition and restore nitrogen-sensitive habitats, while allowing economic development around Natura 2000 areas. The PAS began on $1^{\text {st }}$ July 2015 , and will run for a period of six years (until 2021). Two additional six-year programmes will run until 2033. In total, 118 of the 160 Natura 2000 areas have been identified as 'nitrogen-sensitive areas' (in Dutch: PASgebieden; see Appendix 2), based on the presence of at least one nitrogen-sensitive habitat type (Annex I) or the presence of the a nitrogen-sensitive habitat for species. Measures have been identified that address the causes of nitrogen deposition (sources) and restore the status (quality) of nitrogen-sensitive habitats. The identified restoration measures have been documented in three separate reports (Janssen et al., 2014; Smits \& Bal, 2014a, 2014b), and were identified for each site and habitat based on an ecological assessment.

\subsection{Nitrogen / ammonia sensitivity assessment}

Different systems are used to identify nitrogen-sensitive habitats and species (as well critical loads) in the Netherlands, namely:

- the nature target types (in Dutch: natuurdoeltypen),

- the nature management types (in Dutch: natuurbeheertypen),

- the habitat types listed in Annex I of the Habitats Directive.

The nature target types were developed immediately after the establishment of the national ecological network in 1990 for the purpose of setting conservation objectives at a national and regional scale (Bal et al., 2001). This typology has been used for all types of assessments, including the PBL's estimation of the critical loads of nitrogen for habitats in the Netherlands (Figure 9). In around 2009, the nature target types were replaced by nature management types, also known as the 'Index Nature and Landscape' (see https://www.bij12.nl/onderwerpen/natuur-en-landschap/index-natuur-enlandschap/de-index-natuur-en-landschap/). The subsidies for nature conservation measures are based on this typology (e.g. the calculation of management costs per ha). The nature management types are used by (subsidised) nature conservation organisations to set conservation objectives at the site level. The PBL will update the calculations presented in Figure 9 based on this new typology. For the purposes of Natura 2000, such as the Natura 2000 management plans, the habitat types (Annex I) are used.

Nitrogen-sensitive habitat types were identified within the context of the PAS (see paragraph 3.4), including the habitats of nitrogen-sensitive species (not part of Annex I of the Habitats Directive). The 
latter are based on the original nature target types. The identification of nitrogen-sensitive habitats is based on the abiotic nutrient requirements of the habitat. The threshold critical loads of nitrogen are then calculated based on these requirements, as described by Dobben et al. (2012).

In the Netherlands, the critical load (of a combination of NHy and NOx) is used. Critical load calculations are based on a combination of model predictions and empirical data, which is the same approach used for all nature classification systems (see Dobben et al., 2012). The critical loads are calculated based on the assumption that the habitat types are under a regular management regime (e.g. mowing or grazing regime).

The Netherlands regulates nitrogen critical loads; if the nitrogen deposition on a Natura 2000 site is too high, restorative management approaches are often applied to lower (mitigate) the effect of this deposition, e.g. by mowing or sod cutting. These measures are often subsidised by the government, including within the context of the PAS (see paragraph 3.4). The further expansion of pollution sources is often blocked, or the polluting companies are required to compensate the damage; for example, by paying for additional restorative management, by creating new natural areas, or by investing in the protection of a species. For areas outside the Natura 2000 sites, the effects of nitrogen pollution are still mitigated by subsidised management, but the regulation of polluters is less strict.

Nitrogen deposition in the Natura 2000 areas is calculated based on the different nitrogen sources, meteorological conditions, surface roughness and land cover. A specialised tool, 'AERIUS'

(https://www.aerius.nl/en), was developed for this purpose. These calculations are performed on a site level, and are more accurate than the calculations of the PBL at a national scale (Figure 9).

\subsection{Implementation of the national monitoring programmes}

The national monitoring programmes were developed for different purposes at different times. The NEM programme began in 1999. The national monitoring of ecosystem quality, linked to the subsidies for nature conservation (SNL) and including the mapping and monitoring of the Natura 2000 habitat types, started in 2015.

\subsection{Implementation of the Natura 2000 management plans}

Dutch law states that management plans must be developed for Natura 2000 sites in the Netherlands within three years of their designation. Most SPAs were designated in 2000, with the first SACs being designated in 2007 (see section 2.8). Almost all proposed Natura 2000 areas were supposed to have been designated at this point (June 2017); however, the process of developing the management plans is still ongoing (Figure 10). 


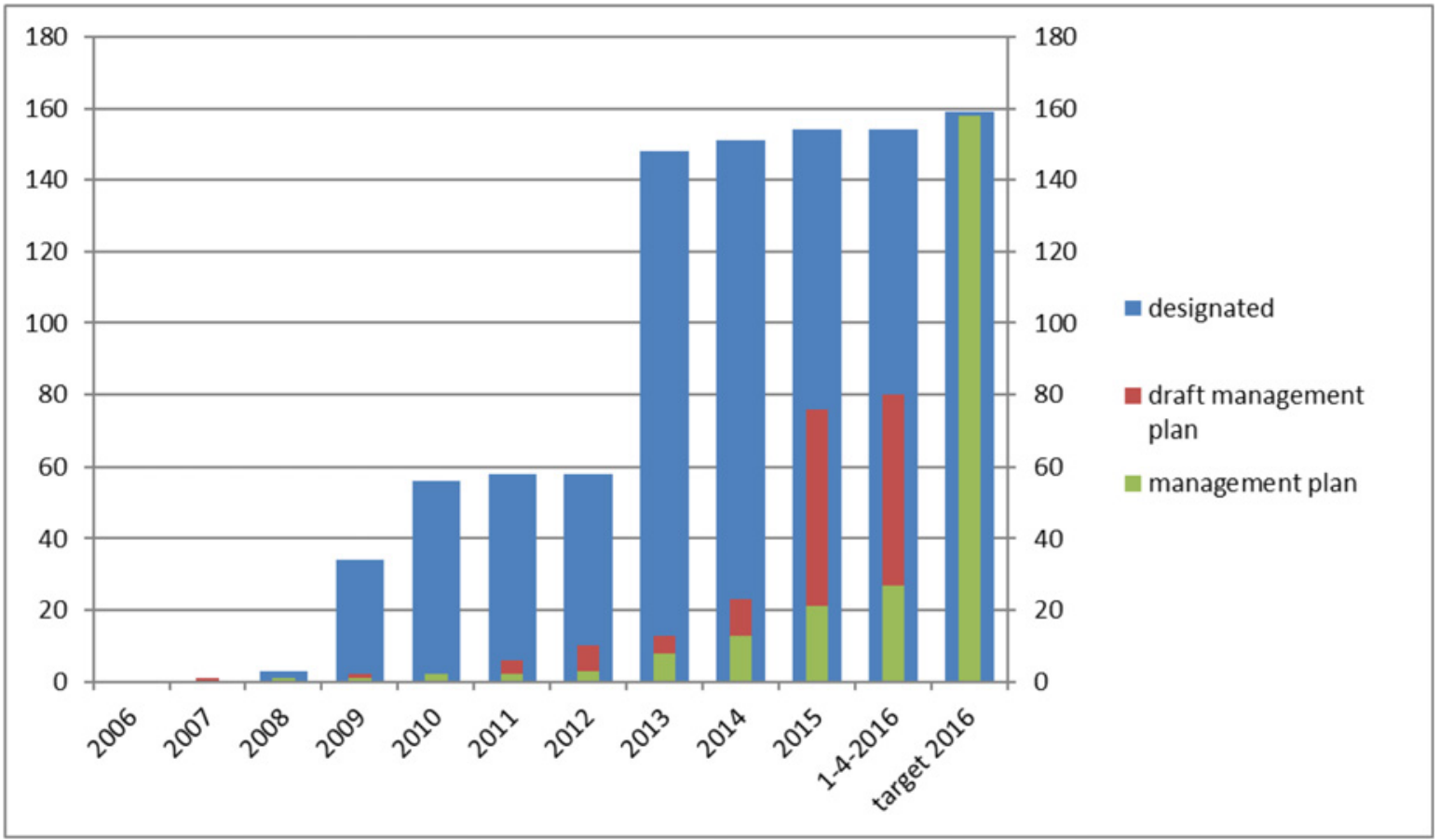

Figure 10 Number of draft and final management plans for designated Natura 2000 areas from 2006 until 2016 (status as of July 2016). The number of management in 2017 are the expected amount (the target). This target has not been met.

\subsection{Monitoring and assessing the (biological) effects of the Natura 2000 management plans (period 2004- 2015)}

It is difficult to determine the biological effects of the Natura 2000 management plans based on monitoring data collected during the period 2004-2015, particularly in terms of how the implementation of these plans may have led to the observed trends in, for example, the population size of species.

During this period and over the last two years, standardised methods have been developed to acquire the necessary data and assess the quantitative and qualitative aspects of these habitats. This process is still on going and the monitoring and assessments on site level are not fully operational yet. 


\section{References}

Backes, C. and A. Keessen (2017). The Netherlands - national report on the legal framework for ammonia regulation of livestock installations with particular regard to Natura 2000 sites. Utrecht University. September 2017.

Bal, D., H.M. Beije, M. Felliger, R. Haveman, A.J.F.M. van Opstal en F.J. van Zadelhoff (2001). Handboek natuurdoeltypen. Rapport Expertisecentrum LNV 2001/020, Wageningen.

Dobben, H.F. van, R. Bobbink, D. Bal en A. van Hinsberg (2012). Overzicht van kritische depositiewaarden voor stikstof, toegepast op habitattypen en leefgebieden van Natura 2000. Wageningen, Alterra, Alterra-rapport 2397.

Jansen, A.J.M., H.F. van Dobben, J.H. Bouwman \& M.E. Nijssen (2014). Herstelstrategieën stikstofgevoelige habitats. Ecologische onderbouwing van de Programmatische Aanpak Stikstof (PAS). Deel III: Landschapsecologische inbedding'. Unie van Bosgroepen, Alterra Wageningen UR, Stichting Bargerveen \& Programmadirectie Natura 2000, Ministerie van Economische zaken.

Programma Aanpak Stikstof 2015-2021. Ontwerp partiële herziening 7 september 2015. Ministerie van Economische Zaken en Ministerie van Infrastructuur. Publicatie-nr. 87208.

Smits, N.A.C. en Bal D. (2014a). Herstelstrategieën stikstofgevoelige habitats. Ecologische onderbouwing van de Programmatische Aanpak Stikstof (PAS). Deel I: Algemene inleiding herstelstrategieën: beleid, kennis en maatregelen. Alterra Wageningen UR \& Programmadirectie Natura 2000 van het Ministerie van Economische zaken.

Smits, N.A.C. en Bal D. (2014b). Herstelstrategieën stikstofgevoelige habitats. Ecologische onderbouwing van de Programmatische Aanpak Stikstof (PAS). Deel II: Herstelstrategieën voor stikstofgevoelige habitats. Alterra Wageningen UR \& Programmadirectie Natura 2000 van het Ministerie van Economische zaken.

Vonk, J., A. Bannink, C. van Bruggen, C.M. Groenestein, J.F.M. Huijsmans, J.W.H. van der Kolk, H.H. Luesink, S.V. Oude Voshaar, S.M. van der Sluis \& G.L. Velthof (2014). Methodology for estimating emissions from agriculture in the Netherlands. Calculations of $\mathrm{CH} 4, \mathrm{NH} 3, \mathrm{~N} 2 \mathrm{O}, \mathrm{NOx}$, PM10, PM2.5 and CO2 with the National Emission Model for Agriculture (NEMA). WOt-technical report 53. 


\section{Appendix 1 Natura 2000 areas in the Netherlands}

Source: Standard Data Forms, version $10^{\text {th }}$ October 2016

\begin{tabular}{|c|c|c|c|}
\hline Code & Name & SAC & SPA \\
\hline 1 & Waddenzee & yes & yes \\
\hline 2 & Duinen en Lage Land Texel & yes & yes \\
\hline 4 & Duinen Terschelling & yes & yes \\
\hline 5 & Duinen Ameland & yes & yes \\
\hline 7 & Noordzeekustzone & yes & yes \\
\hline 8 & Lauwersmeer & no & yes \\
\hline 9 & Groote Wielen & yes & yes \\
\hline 10 & Oudegaasterbrekken, Fluessen en omgeving & yes & yes \\
\hline 14 & Deelen & no & yes \\
\hline 15 & Van Oordt's Mersken & yes & yes \\
\hline 16 & Wijnjeterper Schar & yes & no \\
\hline 17 & Bakkeveense Duinen & yes & no \\
\hline 18 & Rottige Meenthe \& Brandemeer & yes & no \\
\hline 19 & Leekstermeergebied & no & yes \\
\hline 20 & Zuidlaardermeergebied & no & yes \\
\hline 21 & Lieftinghsbroek & yes & no \\
\hline 22 & Norgerholt & yes & no \\
\hline 28 & Elperstroomgebied & yes & no \\
\hline 29 & Holtingerveld & yes & no \\
\hline 30 & Dwingelderveld & yes & yes \\
\hline 31 & Mantingerbos & yes & no \\
\hline 32 & Mantingerzand & yes & no \\
\hline 33 & Bargerveen & yes & yes \\
\hline 34 & Weerribben & yes & yes \\
\hline 35 & De Wieden & yes & yes \\
\hline 36 & Uiterwaarden Zwarte Water en Vecht & yes & yes \\
\hline 37 & Olde Maten \& Veerslootlanden & yes & no \\
\hline 38 & Rijntakken & yes & yes \\
\hline 39 & Vecht- en Beneden-Reggegebied & yes & no \\
\hline 40 & Engbertsdijksvenen & yes & yes \\
\hline 41 & Boetelerveld & yes & \\
\hline 42 & Sallandse Heuvelrug & yes & yes \\
\hline 43 & Wierdense Veld & yes & no \\
\hline 44 & Borkeld & yes & no \\
\hline
\end{tabular}




\begin{tabular}{|c|c|c|c|}
\hline Code & Name & SAC & SPA \\
\hline 53 & Buurserzand \& Haaksbergerveen & yes & no \\
\hline 54 & Witte Veen & yes & no \\
\hline 55 & Aamsveen & yes & no \\
\hline 56 & Arkemheen & no & yes \\
\hline 57 & Veluwe & yes & yes \\
\hline 58 & Landgoederen Brummen & yes & no \\
\hline 60 & Stelkampsveld & yes & no \\
\hline 61 & Korenburgerveen & yes & no \\
\hline 62 & Willinks Weust & yes & no \\
\hline 63 & Bekendelle & yes & no \\
\hline 64 & Wooldse Veen & yes & no \\
\hline 65 & Binnenveld & yes & no \\
\hline 69 & De Bruuk & yes & no \\
\hline 70 & Lingegebied \& Diefdijk-Zuid & yes & no \\
\hline 71 & Loevestein, Pompveld \& Kornsche Boezem & yes & no \\
\hline 72 & IJsselmeer & yes & yes \\
\hline 73 & Markermeer \& IJmeer & yes & yes \\
\hline 74 & Zwarte Meer & yes & yes \\
\hline 75 & Ketelmeer \& Vossemeer & no & yes \\
\hline 76 & Veluwerandmeren & yes & yes \\
\hline 77 & Eemmeer \& Gooimeer Zuidoever & no & yes \\
\hline 78 & Oostvaardersplassen & no & yes \\
\hline 79 & Lepelaarplassen & no & yes \\
\hline 81 & Kolland \& Overlangbroek & yes & no \\
\hline 82 & Uiterwaarden Lek & yes & no \\
\hline 83 & Botshol & yes & no \\
\hline 84 & Duinen Den Helder - Callantsoog & yes & no \\
\hline 85 & Zwanenwater \& Pettemerduinen & yes & yes \\
\hline 86 & Schoorlse Duinen & yes & no \\
\hline 87 & Noordhollands Duinreservaat & yes & no \\
\hline 88 & Kennemerland-Zuid & yes & no \\
\hline 89 & Eilandspolder & yes & yes \\
\hline 90 & Wormer- en Jisperveld \& Kalverpolder & yes & yes \\
\hline 91 & Polder Westzaan & yes & no \\
\hline 92 & Ilperveld, Varkensland, Oostzanerveld \& Twiske & yes & yes \\
\hline 93 & Polder Zeevang & no & yes \\
\hline 94 & Naardermeer & yes & yes \\
\hline 95 & Oostelijke Vechtplassen & yes & yes \\
\hline 96 & Coepelduynen & yes & no \\
\hline 97 & Meijendel \& Berkheide & yes & no \\
\hline 98 & Westduinpark \& Wapendal & yes & no \\
\hline 99 & Solleveld \& Kapittelduinen & yes & no \\
\hline 100 & Voornes Duin & yes & yes \\
\hline 101 & Duinen Goeree \& Kwade Hoek & yes & yes \\
\hline 102 & De Wilck & no & yes \\
\hline 103 & Nieuwkoopse Plassen \& de Haeck & yes & yes \\
\hline 104 & Broekvelden, Vettenbroek \& Polder Stein & no & yes \\
\hline 105 & Zouweboezem & yes & yes \\
\hline 106 & Boezems Kinderdijk & no & yes \\
\hline 107 & Donkse Laagten & no & yes \\
\hline 108 & Oude Maas & yes & no \\
\hline 109 & Haringvliet & yes & yes \\
\hline 110 & Oudeland van Strijen & no & yes \\
\hline 111 & Hollands Diep & yes & yes \\
\hline 112 & Biesbosch & yes & yes \\
\hline 113 & Voordelta & yes & yes \\
\hline 114 & Krammer-Volkerak ${ }^{1}$ & yes & yes \\
\hline 115 & Grevelingen & yes & yes \\
\hline
\end{tabular}




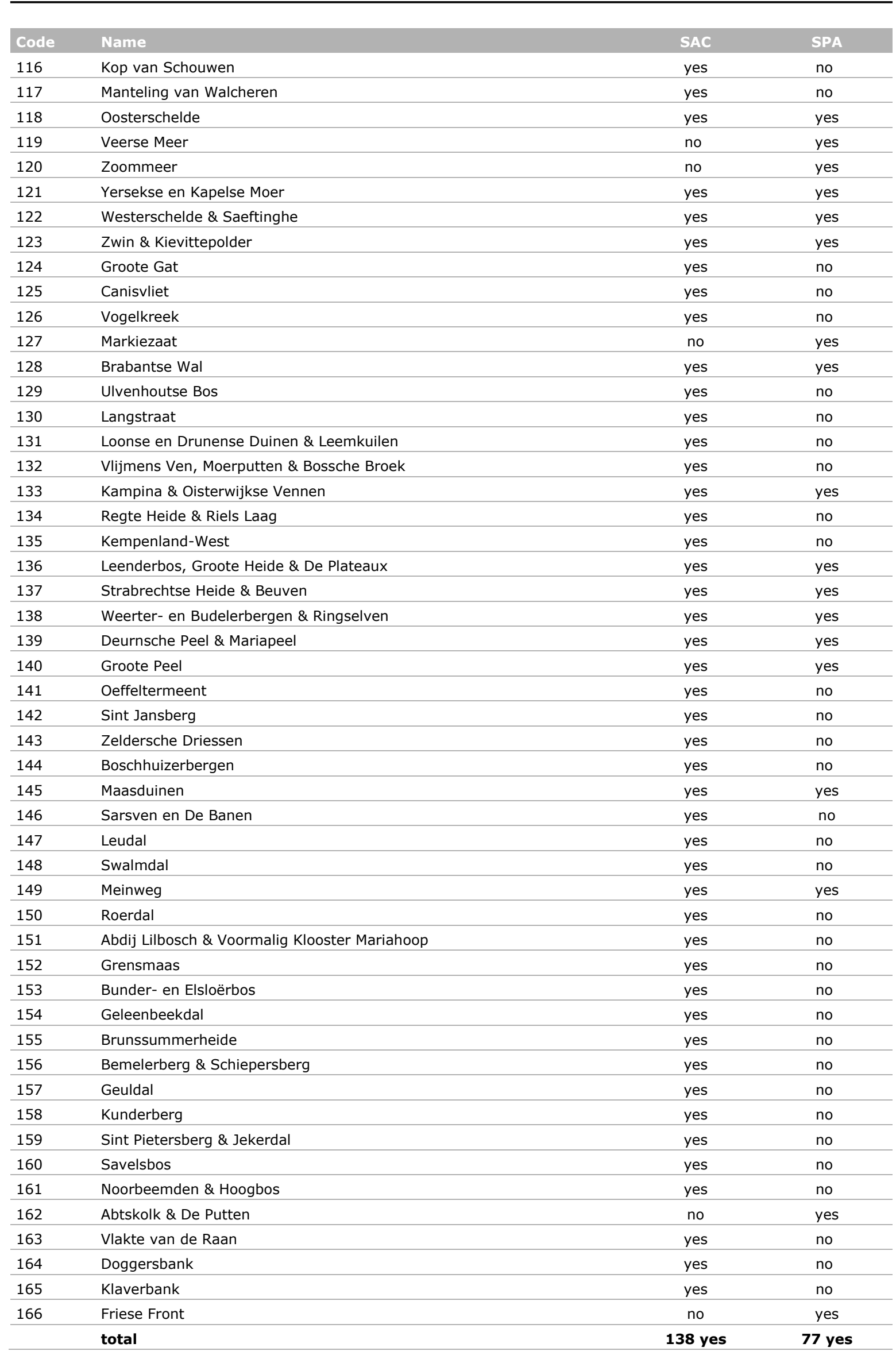

One SCI is not yet designated as a SAC 


\section{Appendix 2 Nitrogen-sensitive Special Areas of Conservation in the Netherlands}

Source: Standard Data Forms, version 10th October 2016 + PAS documents

PAS: 'Programma Aanpak Stikstof'. These Natura 2000 areas are considered nitrogen sensitive.

\begin{tabular}{|c|c|c|c|c|}
\hline Code & Name & Area (ha) & $\begin{array}{l}\text { Habitat types } \\
\text { present (\#) }\end{array}$ & $\begin{array}{l}\text { Nitrogen- } \\
\text { sensitive }\end{array}$ \\
\hline 1 & Waddenzee & 264858 & 11 & yes \\
\hline 2 & Duinen en Lage Land Texel & 4083 & 13 & yes \\
\hline 3 & Duinen Vlieland & 1484 & 10 & yes \\
\hline 4 & Duinen Terschelling & 4040 & 14 & yes \\
\hline 5 & Duinen Ameland & 2055 & 9 & yes \\
\hline 6 & Duinen Schiermonnikoog & 833 & 9 & yes \\
\hline 7 & Noordzeekustzone & 144475 & 6 & no \\
\hline 9 & Groote Wielen & 604 & 0 & no \\
\hline 10 & Oudegaasterbrekken, Fluessen en omgeving & 3054 & 2 & no \\
\hline 13 & Alde Feanen & 2124 & 6 & yes \\
\hline 15 & Van Oordt's Mersken & 536 & 3 & yes \\
\hline 16 & Wijnjeterper Schar & 170 & 5 & yes \\
\hline 17 & Bakkeveense Duinen & 258 & 5 & yes \\
\hline 18 & Rottige Meenthe \& Brandemeer & 1369 & 6 & yes \\
\hline 21 & Lieftinghsbroek & 20 & 4 & yes \\
\hline 22 & Norgerholt & 26 & 1 & yes \\
\hline 23 & Fochteloërveen & 2596 & 5 & yes \\
\hline 24 & Witterveld & 481 & 5 & yes \\
\hline 25 & Drentsche Aa-gebied & 3902 & 19 & yes \\
\hline 26 & Drouwenerzand & 222 & 5 & yes \\
\hline 27 & Drents-Friese Wold \& Leggelderveld & 7466 & 14 & yes \\
\hline 28 & Elperstroomgebied & 351 & 4 & yes \\
\hline 29 & Holtingerveld & 1754 & 11 & yes \\
\hline 30 & Dwingelderveld & 3768 & 14 & yes \\
\hline 31 & Mantingerbos & 46 & 1 & yes \\
\hline 32 & Mantingerzand & 780 & 10 & yes \\
\hline 33 & Bargerveen & 2083 & 3 & yes \\
\hline 34 & Weerribben & 3280 & 8 & yes \\
\hline 35 & De Wieden & 7156 & 8 & yes \\
\hline 36 & Uiterwaarden Zwarte Water en Vecht & 1080 & 6 & yes \\
\hline 37 & Olde Maten \& Veerslootlanden & 795 & 3 & yes \\
\hline 38 & Rijntakken & 8364 & 8 & yes \\
\hline 39 & Vecht- en Beneden-Reggegebied & 4105 & 16 & yes \\
\hline 40 & Engbertsdijksvenen & 998 & 3 & yes \\
\hline 41 & Boetelerveld & 171 & 6 & yes \\
\hline 42 & Sallandse Heuvelrug & 2217 & 6 & yes \\
\hline 43 & Wierdense Veld & 419 & 4 & yes \\
\hline 44 & Borkeld & 493 & 7 & yes \\
\hline 45 & Springendal \& Dal van de Mosbeek & 1225 & 10 & yes \\
\hline 46 & Bergvennen \& Brecklenkampse Veld & 133 & 11 & yes \\
\hline 47 & Achter de Voort, Agelerbroek \& Voltherbroek & 323 & 4 & yes \\
\hline 48 & Lemselermaten & 55 & 6 & yes \\
\hline 49 & Dinkelland & 532 & 16 & yes \\
\hline 50 & Landgoederen Oldenzaal & 578 & 3 & yes \\
\hline 51 & Lonnekermeer & 105 & 7 & yes \\
\hline 53 & Buurserzand \& Haaksbergerveen & 1243 & 10 & yes \\
\hline
\end{tabular}




\begin{tabular}{|c|c|c|c|c|}
\hline Code & Name & Area (ha) & $\begin{array}{l}\text { Habitat types } \\
\text { present (\#) }\end{array}$ & $\begin{array}{l}\text { Nitrogen- } \\
\text { sensitive }\end{array}$ \\
\hline 54 & Witte Veen & 290 & 6 & yes \\
\hline 55 & Aamsveen & 144 & 10 & yes \\
\hline 57 & Veluwe & 88378 & 18 & yes \\
\hline 58 & Landgoederen Brummen & 677 & 7 & yes \\
\hline 60 & Stelkampsveld & 102 & 8 & yes \\
\hline 61 & Korenburgerveen & 459 & 9 & yes \\
\hline 62 & Willinks Weust & 52 & 5 & yes \\
\hline 63 & Bekendelle & 88 & 3 & yes \\
\hline 64 & Wooldse Veen & 63 & 3 & yes \\
\hline 65 & Binnenveld & 111 & 2 & yes \\
\hline 69 & De Bruuk & 99 & 1 & yes \\
\hline 70 & Lingegebied \& Diefdijk-Zuid & 750 & 3 & yes \\
\hline 71 & Loevestein, Pompveld \& Kornsche Boezem & 750 & 5 & yes \\
\hline 72 & IJsselmeer & 2441 & 3 & no \\
\hline 73 & Markermeer \& IJmeer & 1109 & 1 & no \\
\hline 74 & Zwarte Meer & 2162 & 3 & no \\
\hline 76 & Veluwerandmeren & 6166 & 2 & no \\
\hline 81 & Kolland \& Overlangbroek & 107 & 1 & yes \\
\hline 82 & Uiterwaarden Lek & 148 & 4 & yes \\
\hline 83 & Botshol & 218 & 6 & yes \\
\hline 84 & Duinen Den Helder - Callantsoog & 645 & 8 & yes \\
\hline 85 & Zwanenwater \& Pettemerduinen & 770 & 11 & yes \\
\hline 86 & Schoorlse Duinen & 1737 & 10 & yes \\
\hline 87 & Noordhollands Duinreservaat & 5242 & 10 & yes \\
\hline 88 & Kennemerland-Zuid & 8171 & 8 & yes \\
\hline 89 & Eilandspolder & 798 & 2 & yes \\
\hline 90 & Wormer- en Jisperveld \& Kalverpolder & 1453 & 4 & yes \\
\hline 91 & Polder Westzaan & 1057 & 4 & yes \\
\hline 92 & Ilperveld, Varkensland, Oostzanerveld \& Twiske & 1910 & 5 & yes \\
\hline 94 & Naardermeer & 1151 & 6 & yes \\
\hline 95 & Oostelijke Vechtplassen & 4401 & 8 & yes \\
\hline 96 & Coepelduynen & 188 & 4 & yes \\
\hline 97 & Meijendel \& Berkheide & 2878 & 5 & yes \\
\hline 98 & Westduinpark \& Wapendal & 246 & 5 & yes \\
\hline 99 & Solleveld \& Kapittelduinen & 827 & 6 & yes \\
\hline 100 & Voornes Duin & 1432 & 6 & yes \\
\hline 101 & Duinen Goeree \& Kwade Hoek & 1624 & 10 & yes \\
\hline 103 & Nieuwkoopse Plassen \& de Haeck & 2008 & 8 & yes \\
\hline 105 & Zouweboezem & 257 & 3 & yes \\
\hline 108 & Oude Maas & 474 & 3 & no \\
\hline 109 & Haringvliet & 10988 & 3 & no \\
\hline 111 & Hollands Diep & 591 & 3 & no \\
\hline 112 & Biesbosch & 9640 & 6 & yes \\
\hline 113 & Voordelta & 83534 & 6 & \\
\hline 114 & Krammer-Volkerak $^{1}$ & 6081 & 3 & yes \\
\hline 115 & Grevelingen & 13753 & 7 & yes \\
\hline 116 & Kop van Schouwen & 2242 & 9 & yes \\
\hline 117 & Manteling van Walcheren & 735 & 5 & yes \\
\hline 118 & Oosterschelde & 36976 & 5 & yes \\
\hline 121 & Yersekse en Kapelse Moer & 433 & 2 & no \\
\hline 122 & Westerschelde \& Saeftinghe & 44052 & 9 & yes \\
\hline 123 & Zwin \& Kievittepolder & 121 & 7 & yes \\
\hline 124 & Groote Gat & 70 & 2 & no \\
\hline 125 & Canisvliet & 141 & 0 & no \\
\hline 126 & Vogelkreek & 97 & 0 & no \\
\hline 128 & Brabantse Wal & 1775 & 6 & yes \\
\hline 129 & Ulvenhoutse Bos & 112 & 3 & yes \\
\hline 130 & Langstraat & 506 & 4 & yes \\
\hline
\end{tabular}




\begin{tabular}{|c|c|c|c|c|}
\hline Code & Name & Area (ha) & $\begin{array}{l}\text { Habitat types } \\
\text { present (\#) }\end{array}$ & $\begin{array}{l}\text { Nitrogen- } \\
\text { sensitive }\end{array}$ \\
\hline 131 & Loonse en Drunense Duinen \& Leemkuilen & 3975 & 7 & yes \\
\hline 132 & Vlijmens Ven, Moerputten \& Bossche Broek & 897 & 5 & yes \\
\hline 133 & Kampina \& Oisterwijkse Vennen & 2278 & 13 & yes \\
\hline 134 & Regte Heide \& Riels Laag & 538 & 7 & yes \\
\hline 135 & Kempenland-West & 1882 & 9 & yes \\
\hline 136 & Leenderbos, Groote Heide \& De Plateaux & 4390 & 16 & yes \\
\hline 137 & Strabrechtse Heide \& Beuven & 1843 & 8 & yes \\
\hline 138 & Weerter- en Budelerbergen \& Ringselven & 1139 & 3 & yes \\
\hline 139 & Deurnsche Peel \& Mariapeel & 2734 & 3 & yes \\
\hline 140 & Groote Peel & 1348 & 2 & yes \\
\hline 141 & Oeffeltermeent & 101 & 2 & yes \\
\hline 142 & Sint Jansberg & 226 & 3 & yes \\
\hline 143 & Zeldersche Driessen & 82 & 4 & yes \\
\hline 144 & Boschhuizerbergen & 277 & 4 & yes \\
\hline 145 & Maasduinen & 5274 & 11 & yes \\
\hline 146 & Sarsven en De Banen & 154 & 3 & yes \\
\hline 147 & Leudal & 340 & 3 & yes \\
\hline 148 & Swalmdal & 123 & 3 & yes \\
\hline 149 & Meinweg & 1822 & 8 & yes \\
\hline 150 & Roerdal & 834 & 4 & yes \\
\hline 151 & Abdij Lilbosch \& Voormalig Klooster Mariahoop & 15 & 0 & no \\
\hline 152 & Grensmaas & 314 & 4 & no \\
\hline 153 & Bunder- en Elsloërbos & 190 & 4 & yes \\
\hline 154 & Geleenbeekdal & 253 & 4 & yes \\
\hline 155 & Brunssummerheide & 542 & 8 & yes \\
\hline 156 & Bemelerberg \& Schiepersberg & 191 & 5 & yes \\
\hline 157 & Geuldal & 2593 & 13 & yes \\
\hline 158 & Kunderberg & 95 & 2 & yes \\
\hline 159 & Sint Pietersberg \& Jekerdal & 256 & 5 & yes \\
\hline 160 & Savelsbos & 357 & 5 & yes \\
\hline 161 & Noorbeemden \& Hoogbos & 55 & 3 & yes \\
\hline 163 & Vlakte van de Raan & 17521 & 1 & no \\
\hline 164 & Doggersbank & 473500 & 1 & no \\
\hline \multirow[t]{2}{*}{165} & Klaverbank & 153900 & 1 & \\
\hline & Total & 1520179 & 817 & 118 yes \\
\hline
\end{tabular}




\section{Appendix 3 Annex I of the Habitats Directive: Habitat types}

Source: Standard Data Forms, version 10th October 2016

\begin{tabular}{|c|c|c|c|}
\hline $\begin{array}{l}\text { habitat } \\
\text { code }\end{array}$ & habitat name & 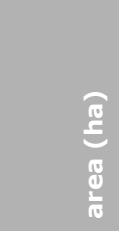 & 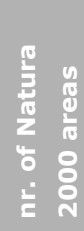 \\
\hline 1110 & Sandbanks which are slightly covered by sea water all the time & 838171 & 6 \\
\hline 1130 & Estuaries & 43664 & 2 \\
\hline 1140 & Mudflats and sandflats not covered by seawater at low tide & 134817 & 6 \\
\hline 1160 & Large shallow inlets and bays & 34700 & 1 \\
\hline 1170 & Reefs & 76934 & 1 \\
\hline 1310 & Salicornia and other annuals colonizing mud and sand & 2250 & 13 \\
\hline 1320 & Spartina swards (Spartinion maritimae) & 787 & 7 \\
\hline 1330 & Atlantic salt meadows (Glauco-Puccinellietalia maritimae) & 10239 & 14 \\
\hline 2110 & Embryonic shifting dunes & 579 & 11 \\
\hline 2120 & Shifting dunes along the shoreline with Ammophila arenaria ('white dunes') & 1903 & 21 \\
\hline 2130 & Fixed coastal dunes with herbaceous vegetation ("grey dunes') & 15660 & 21 \\
\hline 2140 & Decalcified fixed dunes with Empetrum nigrum & 2409 & 8 \\
\hline 2150 & Atlantic decalcified fixed dunes (Calluno-Ulicetea) & 379 & 11 \\
\hline 2160 & Dunes with Hippophaë rhamnoides & 6411 & 21 \\
\hline 2170 & Dunes with Salix repens ssp. argentea (Salicion arenariae) & 835 & 13 \\
\hline 2180 & Wooded dunes of the Atlantic, Continental and Boreal region & 7123 & 16 \\
\hline 2190 & Humid dune slacks & 2538 & 21 \\
\hline 2310 & Dry sand heaths with Calluna and Genista & 2233 & 20 \\
\hline 2320 & Dry sand heaths with Calluna and Empetrum nigrum & 579 & 10 \\
\hline 2330 & Inland dunes with open Corynephorus and Agrostis grasslands & 3169 & 17 \\
\hline 3110 & Oligotrophic waters containing very few minerals of sandy plains (Littorelletalia uniflorae) & 24 & 5 \\
\hline 3130 & $\begin{array}{l}\text { Oligotrophic to mesotrophic standing waters with vegetation of the Littorelletea uniflorae } \\
\text { and/or of the Isoëto-Nanojuncetea }\end{array}$ & 316 & 26 \\
\hline 3140 & Hard oligo-mesotrophic waters with benthic vegetation of Chara spp. & 5685 & 13 \\
\hline 3150 & Natural eutrophic lakes with Magnopotamion or Hydrocharition - type vegetation & 1612 & 17 \\
\hline 3160 & Natural dystrophic lakes and ponds & 459 & 21 \\
\hline 3260 & $\begin{array}{l}\text { Water courses of plain to montane levels with the Ranunculion fluitantis and Callitricho- } \\
\text { Batrachion vegetation }\end{array}$ & 100 & 13 \\
\hline 3270 & Rivers with muddy banks with Chenopodion rubri p.p. and Bidention p.p. vegetation & 175 & 8 \\
\hline 4010 & Northern Atlantic wet heaths with Erica tetralix & 1946 & 46 \\
\hline 4030 & European dry heaths & 16286 & 34 \\
\hline 5130 & Juniperus communis formations on heaths or calcareous grasslands & 389 & 15 \\
\hline 6110 & Rupicolous calcareous or basophilic grasslands of the Alysso-Sedion albi & 0 & 4 \\
\hline 6120 & Xeric sand calcareous grasslands & 178 & 12 \\
\hline 6130 & Calaminarian grasslands of the Violetalia calaminariae & 1 & 1 \\
\hline 6210 & $\begin{array}{l}\text { Semi-natural dry grasslands and scrubland facies on calcareous substrates (Festuco- } \\
\text { Brometalia) (* important orchid sites) }\end{array}$ & 52 & 5 \\
\hline 6230 & $\begin{array}{l}\text { Species-rich Nardus grasslands, on silicious substrates in mountain areas (and } \\
\text { submountain areas in Continental Europe) }\end{array}$ & 492 & 35 \\
\hline 6410 & Molinia meadows on calcareous, peaty or clayey-silt-laden soils (Molinion caeruleae) & 231 & 42 \\
\hline 6430 & Hydrophilous tall herb fringe communities of plains and of the montane to alpine levels & 1364 & 32 \\
\hline 6510 & Lowland hay meadows (Alopecurus pratensis, Sanguisorba officinalis) & 555 & 13 \\
\hline 7110 & Active raised bogs & 102 & 23 \\
\hline 7120 & Degraded raised bogs still capable of natural regeneration & 5922 & 13 \\
\hline 7140 & Transition mires and quaking bogs & 1360 & 24 \\
\hline 7150 & Depressions on peat substrates of the Rhynchosporion & 204 & 26 \\
\hline
\end{tabular}




\begin{tabular}{|c|c|c|c|}
\hline $\begin{array}{l}\text { habitat } \\
\text { code }\end{array}$ & habitat name & 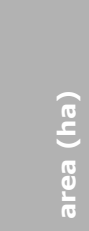 & 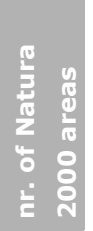 \\
\hline 7210 & Calcareous fens with Cladium mariscus and species of the Caricion davallianae & 92 & 15 \\
\hline 7220 & Petrifying springs with tufa formation (Cratoneurion) & 2 & 3 \\
\hline 7230 & Alkaline fens & 8 & 11 \\
\hline 9110 & Luzulo-Fagetum beech forests & 492 & 1 \\
\hline 9120 & $\begin{array}{l}\text { Atlantic acidophilous beech forests with Ilex and sometimes also Taxus in the shrublayer } \\
\text { (Quercion robori-petraeae or Ilici-Fagenion) }\end{array}$ & 6969 & 20 \\
\hline 9160 & Sub-Atlantic and medio-European oak or oak-hornbeam forests of the Carpinion betuli & 826 & 17 \\
\hline 9190 & Old acidophilous oak woods with Quercus robur on sandy plains & 2301 & 10 \\
\hline 91D0 & Bog woodland & 551 & 25 \\
\hline 91E0 & $\begin{array}{l}\text { Alluvial forests with Alnus glutinosa and Fraxinus excelsior (Alno-Padion, Alnion incanae, } \\
\text { Salicion albae) }\end{array}$ & 4271 & 41 \\
\hline $91 \mathrm{FO}$ & $\begin{array}{l}\text { Riparian mixed forests of Quercus robur, Ulmus laevis and Ulmus minor, Fraxinus } \\
\text { excelsior or Fraxinus angustifolia, along the great rivers (Ulmenion minoris) }\end{array}$ & 57 & 3 \\
\hline
\end{tabular}




\section{Appendix 4 Species of Annex II of the Habitat Directive}

Source: Standard Data Forms, version 10th October 2016

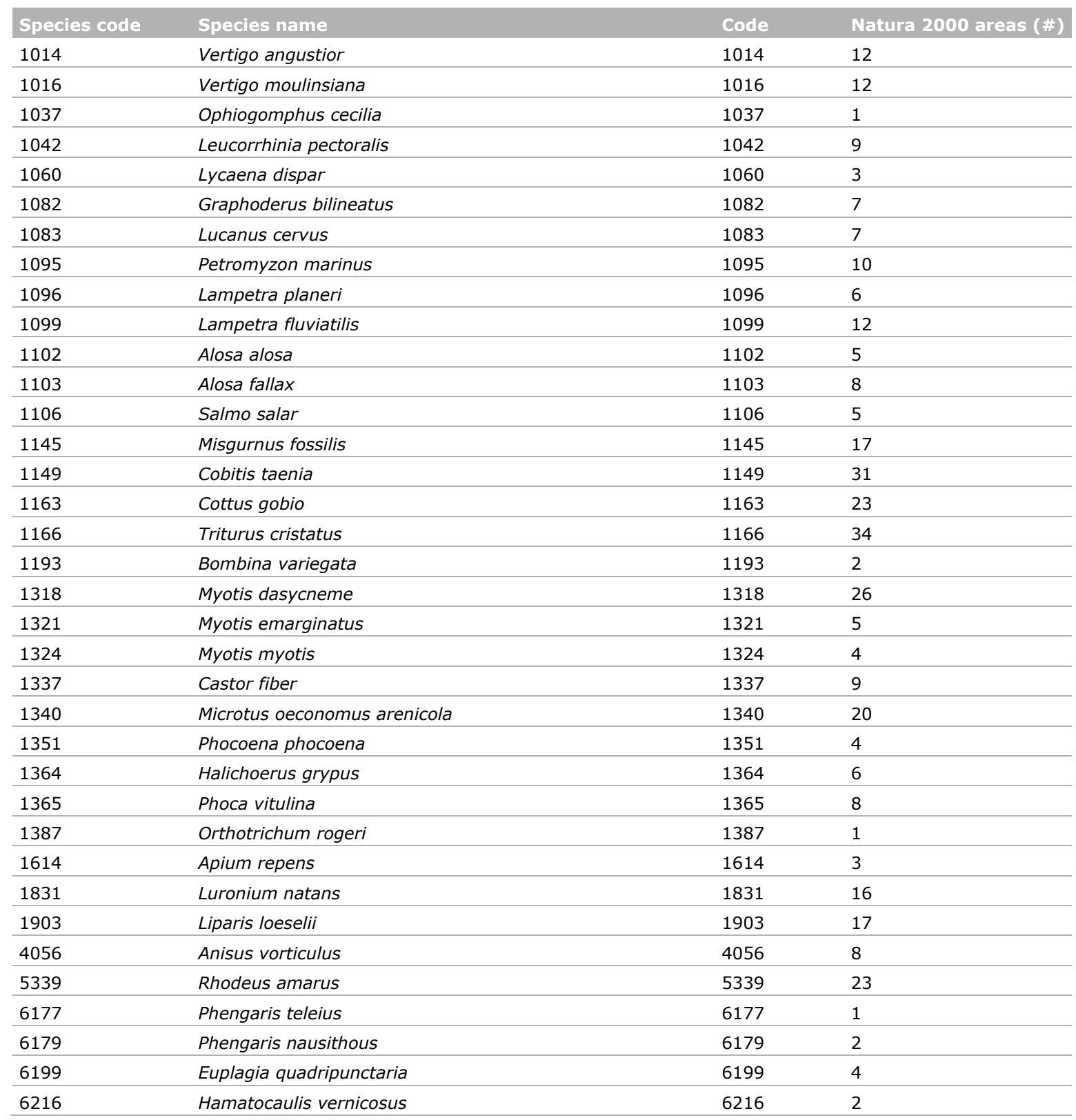




\section{Appendix 5 Percentage of Natura 2000 areas subjected to intensive agriculture}

The percentage of each Natura 2000 area comprising 'intensive agricultural production' (including or excluding permanent grasslands), based on the combined analysis of data from the Land Parcel Identification System (in Dutch: Basisregistratie Percelen, BRP) and the Geographic Information System for Agricultural Holdings (in Dutch: Geografisch Informatiesysteem Agrarische Bedrijven, GIAB).

\begin{tabular}{|c|c|c|c|c|c|c|c|}
\hline ஜூ & Name & ư & 彳亍 & $\frac{y}{\alpha}$ & 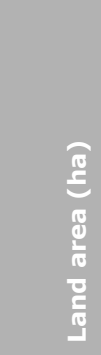 & 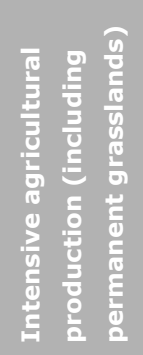 & 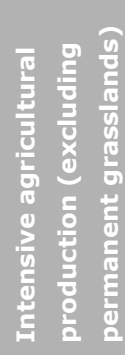 \\
\hline 1 & Waddenzee & yes & yes & yes & 12378 & $22 \%$ & $13 \%$ \\
\hline 2 & Duinen en Lage Land Texel & yes & yes & yes & 4083 & $9 \%$ & $4 \%$ \\
\hline 3 & Duinen Vlieland & yes & yes & yes & 1482 & $0 \%$ & $0 \%$ \\
\hline 4 & Duinen Terschelling & yes & yes & yes & 4023 & $2 \%$ & $0 \%$ \\
\hline 5 & Duinen Ameland & yes & yes & yes & 2055 & $5 \%$ & $2 \%$ \\
\hline 6 & Duinen Schiermonnikoog & yes & yes & yes & 833 & $3 \%$ & $3 \%$ \\
\hline 7 & Noordzeekustzone & yes & yes & no & & & \\
\hline 8 & Lauwersmeer & no & yes & no & 5755 & $9 \%$ & $6 \%$ \\
\hline 9 & Groote Wielen & yes & yes & no & 604 & $55 \%$ & $32 \%$ \\
\hline 10 & Oudegaasterbrekken, Fluessen en omgeving & yes & yes & no & 3054 & $14 \%$ & $7 \%$ \\
\hline 11 & Witte en Zwarte Brekken & no & yes & no & 433 & $24 \%$ & $3 \%$ \\
\hline 12 & Sneekermeergebied & no & yes & no & 2279 & $34 \%$ & $23 \%$ \\
\hline 13 & Alde Feanen & yes & yes & yes & 2124 & $25 \%$ & $15 \%$ \\
\hline 14 & Deelen & no & yes & no & 514 & $14 \%$ & $9 \%$ \\
\hline 15 & Van Oordt's Mersken & yes & yes & yes & 842 & $60 \%$ & $33 \%$ \\
\hline 16 & Wijnjeterper Schar & yes & no & yes & 170 & $7 \%$ & $5 \%$ \\
\hline 17 & Bakkeveense Duinen & yes & no & yes & 258 & $10 \%$ & $10 \%$ \\
\hline 18 & Rottige Meenthe \& Brandemeer & yes & no & yes & 1369 & $12 \%$ & $5 \%$ \\
\hline 19 & Leekstermeergebied & no & yes & no & 1543 & $28 \%$ & $10 \%$ \\
\hline 20 & Zuidlaardermeergebied & no & yes & no & 2087 & $19 \%$ & $9 \%$ \\
\hline 21 & Lieftinghsbroek & yes & no & yes & 20 & $10 \%$ & $10 \%$ \\
\hline 22 & Norgerholt & yes & no & yes & 26 & $0 \%$ & $0 \%$ \\
\hline 23 & Fochteloërveen & yes & yes & yes & 2596 & $1 \%$ & $0 \%$ \\
\hline 24 & Witterveld & yes & no & yes & 481 & $5 \%$ & $2 \%$ \\
\hline 25 & Drentsche Aa-gebied & yes & no & yes & 3902 & $42 \%$ & $30 \%$ \\
\hline 26 & Drouwenerzand & yes & no & yes & 222 & $1 \%$ & $0 \%$ \\
\hline 27 & Drents-Friese Wold \& Leggelderveld & yes & yes & yes & 7466 & $11 \%$ & $7 \%$ \\
\hline 28 & Elperstroomgebied & yes & no & yes & 351 & $18 \%$ & $11 \%$ \\
\hline 29 & Holtingerveld & yes & no & yes & 1754 & $15 \%$ & $4 \%$ \\
\hline 30 & Dwingelderveld & yes & yes & yes & 3768 & $7 \%$ & $6 \%$ \\
\hline 31 & Mantingerbos & yes & no & yes & 46 & $53 \%$ & $42 \%$ \\
\hline 32 & Mantingerzand & yes & no & yes & 780 & $13 \%$ & $9 \%$ \\
\hline 33 & Bargerveen & yes & yes & yes & 2083 & $8 \%$ & $5 \%$ \\
\hline 34 & Weerribben & yes & yes & yes & 3329 & $7 \%$ & $1 \%$ \\
\hline 35 & De Wieden & yes & yes & yes & 9018 & $28 \%$ & $11 \%$ \\
\hline 36 & Uiterwaarden Zwarte Water en Vecht & yes & yes & yes & 1441 & $59 \%$ & $18 \%$ \\
\hline
\end{tabular}




\begin{tabular}{|c|c|c|c|c|c|c|c|}
\hline 융 & Name & $\frac{3}{4}$ & $\frac{\pi}{n}$ & $\frac{n}{2}$ & 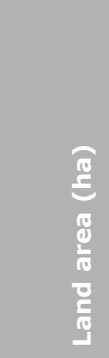 & 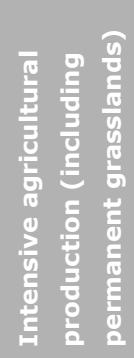 & 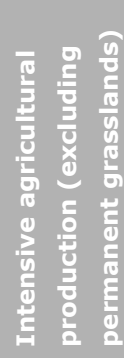 \\
\hline 37 & Olde Maten \& Veerslootlanden & yes & no & yes & 795 & $64 \%$ & $40 \%$ \\
\hline 38 & Rijntakken & yes & yes & yes & 23002 & $53 \%$ & $18 \%$ \\
\hline 39 & Vecht- en Beneden-Reggegebied & yes & no & yes & 4105 & $18 \%$ & $9 \%$ \\
\hline 40 & Engbertsdijksvenen & yes & yes & yes & 998 & $10 \%$ & $9 \%$ \\
\hline 41 & Boetelerveld & yes & no & yes & 171 & $3 \%$ & $3 \%$ \\
\hline 42 & Sallandse Heuvelrug & yes & yes & yes & 2217 & $7 \%$ & $5 \%$ \\
\hline 43 & Wierdense Veld & yes & no & yes & 419 & $4 \%$ & $4 \%$ \\
\hline 44 & Borkeld & yes & no & yes & 493 & $4 \%$ & $4 \%$ \\
\hline 45 & Springendal \& Dal van de Mosbeek & yes & no & yes & 1225 & $29 \%$ & $18 \%$ \\
\hline 46 & Bergvennen \& Brecklenkampse Veld & yes & no & yes & 133 & $22 \%$ & $13 \%$ \\
\hline 47 & Achter de Voort, Agelerbroek \& Voltherbroek & yes & no & yes & 323 & $17 \%$ & $9 \%$ \\
\hline 48 & Lemselermaten & yes & no & yes & 55 & $26 \%$ & $9 \%$ \\
\hline 49 & Dinkelland & yes & no & yes & 532 & $37 \%$ & $8 \%$ \\
\hline 50 & Landgoederen Oldenzaal & yes & no & yes & 578 & $33 \%$ & $8 \%$ \\
\hline 51 & Lonnekermeer & yes & no & yes & 105 & $13 \%$ & $2 \%$ \\
\hline 53 & Buurserzand \& Haaksbergerveen & yes & no & yes & 1243 & $16 \%$ & $9 \%$ \\
\hline 54 & Witte Veen & yes & no & yes & 290 & $32 \%$ & $32 \%$ \\
\hline 55 & Aamsveen & yes & no & yes & 144 & $18 \%$ & $18 \%$ \\
\hline 56 & Arkemheen & no & yes & no & 1422 & $87 \%$ & $6 \%$ \\
\hline 57 & Veluwe & yes & yes & yes & 88436 & $2 \%$ & $1 \%$ \\
\hline 58 & Landgoederen Brummen & yes & no & yes & 677 & $39 \%$ & $25 \%$ \\
\hline 60 & Stelkampsveld & yes & no & yes & 102 & $28 \%$ & $17 \%$ \\
\hline 61 & Korenburgerveen & yes & no & yes & 459 & $21 \%$ & $18 \%$ \\
\hline 62 & Willinks Weust & yes & no & yes & 52 & $20 \%$ & $19 \%$ \\
\hline 63 & Bekendelle & yes & no & yes & 88 & $4 \%$ & $1 \%$ \\
\hline 64 & Wooldse Veen & yes & no & yes & 63 & $7 \%$ & $7 \%$ \\
\hline 65 & Binnenveld & yes & no & yes & 111 & $39 \%$ & $18 \%$ \\
\hline 69 & De Bruuk & yes & no & yes & 99 & $0 \%$ & $0 \%$ \\
\hline 70 & Lingegebied \& Diefdijk-Zuid & yes & no & yes & 750 & $19 \%$ & $14 \%$ \\
\hline 71 & Loevestein, Pompveld \& Kornsche Boezem & yes & no & yes & 750 & $22 \%$ & $11 \%$ \\
\hline 72 & IJsselmeer & yes & yes & no & 1495 & $12 \%$ & $9 \%$ \\
\hline 73 & Markermeer \& IJmeer & yes & yes & no & 358 & $1 \%$ & $1 \%$ \\
\hline 74 & Zwarte Meer & yes & yes & no & 355 & $22 \%$ & $15 \%$ \\
\hline 75 & Ketelmeer \& Vossemeer & no & yes & no & 257 & $13 \%$ & $3 \%$ \\
\hline 76 & Veluwerandmeren & yes & yes & no & 275 & $1 \%$ & $0 \%$ \\
\hline 77 & Eemmeer \& Gooimeer Zuidoever & no & yes & no & 246 & $35 \%$ & $21 \%$ \\
\hline 78 & Oostvaardersplassen & no & yes & no & 5477 & $0 \%$ & $0 \%$ \\
\hline 79 & Lepelaarplassen & no & yes & no & & & \\
\hline 81 & Kolland \& Overlangbroek & yes & no & yes & 107 & $18 \%$ & $0 \%$ \\
\hline 82 & Uiterwaarden Lek & yes & no & yes & 148 & $49 \%$ & $31 \%$ \\
\hline 83 & Botshol & yes & no & yes & 218 & $0 \%$ & $0 \%$ \\
\hline 84 & Duinen Den Helder - Callantsoog & yes & no & yes & 645 & $3 \%$ & $2 \%$ \\
\hline 85 & Zwanenwater \& Pettemerduinen & yes & yes & yes & 770 & $1 \%$ & $1 \%$ \\
\hline 86 & Schoorlse Duinen & yes & no & yes & 1733 & $0 \%$ & $0 \%$ \\
\hline 87 & Noordhollands Duinreservaat & yes & no & yes & 5242 & $1 \%$ & $1 \%$ \\
\hline 88 & Kennemerland-Zuid & yes & no & yes & 8164 & $0 \%$ & $0 \%$ \\
\hline 89 & Eilandspolder & yes & yes & yes & 1397 & $68 \%$ & $22 \%$ \\
\hline 90 & Wormer- en Jisperveld \& Kalverpolder & yes & yes & yes & 1839 & $59 \%$ & $19 \%$ \\
\hline 91 & Polder Westzaan & yes & no & yes & 1057 & $54 \%$ & $9 \%$ \\
\hline 92 & Ilperveld, Varkensland, Oostzanerveld \& Twiske & yes & yes & yes & 2553 & $45 \%$ & $11 \%$ \\
\hline 93 & Polder Zeevang & no & yes & no & 1813 & $80 \%$ & $10 \%$ \\
\hline
\end{tabular}




\begin{tabular}{|c|c|c|c|c|c|c|c|}
\hline 용 & Name & $\frac{3}{4}$ & $\frac{\pi}{\sigma}$ & $\frac{n}{2}$ & 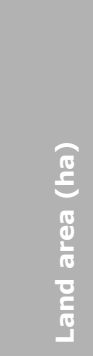 & 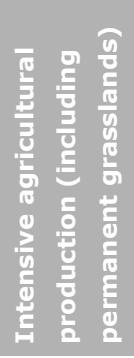 & 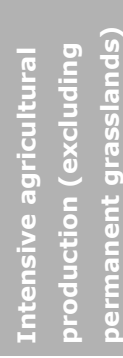 \\
\hline 94 & Naardermeer & yes & yes & yes & 1151 & $19 \%$ & $16 \%$ \\
\hline 95 & Oostelijke Vechtplassen & yes & yes & yes & 6475 & $21 \%$ & $7 \%$ \\
\hline 96 & Coepelduynen & yes & no & yes & 188 & $1 \%$ & $0 \%$ \\
\hline 97 & Meijendel \& Berkheide & yes & no & yes & 2878 & $0 \%$ & $0 \%$ \\
\hline 98 & Westduinpark \& Wapendal & yes & no & yes & 246 & $0 \%$ & $0 \%$ \\
\hline 99 & Solleveld \& Kapittelduinen & yes & no & yes & 771 & $2 \%$ & $0 \%$ \\
\hline 100 & Voornes Duin & yes & yes & yes & 1432 & $1 \%$ & $1 \%$ \\
\hline 101 & Duinen Goeree \& Kwade Hoek & yes & yes & yes & 1164 & $0 \%$ & $0 \%$ \\
\hline 102 & De Wilck & no & yes & no & 116 & $72 \%$ & $43 \%$ \\
\hline 103 & Nieuwkoopse Plassen \& de Haeck & yes & yes & yes & 2008 & $24 \%$ & $5 \%$ \\
\hline 104 & Broekvelden, Vettenbroek \& Polder Stein & no & yes & no & 696 & $53 \%$ & $40 \%$ \\
\hline 105 & Zouweboezem & yes & yes & yes & 257 & $29 \%$ & $29 \%$ \\
\hline 106 & Boezems Kinderdijk & no & yes & no & 331 & $25 \%$ & $3 \%$ \\
\hline 107 & Donkse Laagten & no & yes & no & 190 & $78 \%$ & $69 \%$ \\
\hline 108 & Oude Maas & yes & no & no & 474 & $9 \%$ & $6 \%$ \\
\hline 109 & Haringvliet & yes & yes & no & 2832 & $27 \%$ & $17 \%$ \\
\hline 110 & Oudeland van Strijen & no & yes & no & 1568 & $85 \%$ & $41 \%$ \\
\hline 111 & Hollands Diep & yes & yes & no & 629 & $30 \%$ & $16 \%$ \\
\hline 112 & Biesbosch & yes & yes & yes & 9640 & $6 \%$ & $3 \%$ \\
\hline 113 & Voordelta & yes & yes & no & 567 & $0 \%$ & $0 \%$ \\
\hline 114 & Krammer-Volkerak & yes & yes & yes & 1844 & $8 \%$ & $6 \%$ \\
\hline 115 & Grevelingen & yes & yes & yes & 2598 & $7 \%$ & $5 \%$ \\
\hline 116 & Kop van Schouwen & yes & no & yes & 2241 & $3 \%$ & $2 \%$ \\
\hline 117 & Manteling van Walcheren & yes & no & yes & 735 & $3 \%$ & $2 \%$ \\
\hline 118 & Oosterschelde & yes & yes & yes & 2982 & $14 \%$ & $8 \%$ \\
\hline 119 & Veerse Meer & no & yes & no & 473 & $14 \%$ & $13 \%$ \\
\hline 120 & Zoommeer & no & yes & no & 226 & $0 \%$ & $0 \%$ \\
\hline 121 & Yersekse en Kapelse Moer & yes & yes & no & 433 & $52 \%$ & $42 \%$ \\
\hline 122 & Westerschelde \& Saeftinghe & yes & yes & yes & 3802 & $44 \%$ & $38 \%$ \\
\hline 123 & Zwin \& Kievittepolder & yes & yes & yes & 81 & $0 \%$ & $0 \%$ \\
\hline 124 & Groote Gat & yes & no & no & 70 & $49 \%$ & $46 \%$ \\
\hline 125 & Canisvliet & yes & no & no & 141 & $49 \%$ & $24 \%$ \\
\hline 126 & Vogelkreek & yes & no & no & 97 & $33 \%$ & $23 \%$ \\
\hline 127 & Markiezaat & no & yes & no & 1832 & $11 \%$ & $7 \%$ \\
\hline 128 & Brabantse Wal & yes & yes & yes & 4874 & $5 \%$ & $4 \%$ \\
\hline 129 & Ulvenhoutse Bos & yes & no & yes & 112 & $0 \%$ & $0 \%$ \\
\hline 130 & Langstraat & yes & no & yes & 506 & $58 \%$ & $39 \%$ \\
\hline 131 & Loonse en Drunense Duinen \& Leemkuilen & yes & no & yes & 3975 & $15 \%$ & $9 \%$ \\
\hline 132 & Vlijmens Ven, Moerputten \& Bossche Broek & yes & no & yes & 897 & $28 \%$ & $22 \%$ \\
\hline 133 & Kampina \& Oisterwijkse Vennen & yes & yes & yes & 2278 & $7 \%$ & $4 \%$ \\
\hline 134 & Regte Heide \& Riels Laag & yes & no & yes & 538 & $17 \%$ & $17 \%$ \\
\hline 135 & Kempenland-West & yes & no & yes & 1882 & $4 \%$ & $3 \%$ \\
\hline 136 & Leenderbos, Groote Heide \& De Plateaux & yes & yes & yes & 4390 & $8 \%$ & $7 \%$ \\
\hline 137 & Strabrechtse Heide \& Beuven & yes & yes & yes & 1843 & $8 \%$ & $7 \%$ \\
\hline 138 & Weerter- en Budelerbergen \& Ringselven & yes & yes & yes & 3164 & $7 \%$ & $5 \%$ \\
\hline 139 & Deurnsche Peel \& Mariapeel & yes & yes & yes & 2734 & $4 \%$ & $3 \%$ \\
\hline 140 & Groote Peel & yes & yes & yes & 1348 & $12 \%$ & $11 \%$ \\
\hline 141 & Oeffeltermeent & yes & no & yes & 101 & $61 \%$ & $56 \%$ \\
\hline 142 & Sint Jansberg & yes & no & yes & 226 & $15 \%$ & $13 \%$ \\
\hline 143 & Zeldersche Driessen & yes & no & yes & 82 & $23 \%$ & $23 \%$ \\
\hline 144 & Boschhuizerbergen & yes & no & yes & 277 & $3 \%$ & $3 \%$ \\
\hline
\end{tabular}




\begin{tabular}{|c|c|c|c|c|c|c|c|}
\hline 용 & Name & $\frac{u}{4}$ & $\frac{\pi}{\pi}$ & $\frac{0}{\frac{0}{2}}$ & 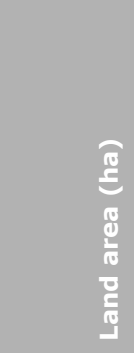 & 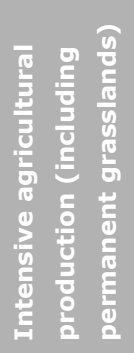 & 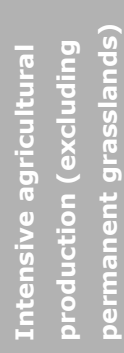 \\
\hline 145 & Maasduinen & yes & yes & yes & 5274 & $9 \%$ & $8 \%$ \\
\hline 146 & Sarsven en De Banen & yes & no & yes & 154 & $29 \%$ & $28 \%$ \\
\hline 147 & Leudal & yes & no & yes & 340 & $6 \%$ & $4 \%$ \\
\hline 148 & Swalmdal & yes & no & yes & 123 & $23 \%$ & $17 \%$ \\
\hline 149 & Meinweg & yes & yes & yes & 1821 & $5 \%$ & $5 \%$ \\
\hline 150 & Roerdal & yes & no & yes & 834 & $60 \%$ & $38 \%$ \\
\hline 151 & Abdij Lilbosch \& Voormalig Klooster Mariahoop & yes & no & no & 15 & $5 \%$ & $0 \%$ \\
\hline 152 & Grensmaas & yes & no & no & 314 & $0 \%$ & $0 \%$ \\
\hline 153 & Bunder- en Elsloërbos & yes & no & yes & 190 & $2 \%$ & $1 \%$ \\
\hline 154 & Geleenbeekdal & yes & no & yes & 253 & $12 \%$ & $4 \%$ \\
\hline 155 & Brunssummerheide & yes & no & yes & 542 & $1 \%$ & $1 \%$ \\
\hline 156 & Bemelerberg \& Schiepersberg & yes & no & yes & 196 & $20 \%$ & $16 \%$ \\
\hline 157 & Geuldal & yes & no & yes & 2724 & $25 \%$ & $15 \%$ \\
\hline 158 & Kunderberg & yes & no & yes & 95 & $60 \%$ & $34 \%$ \\
\hline 159 & Sint Pietersberg \& Jekerdal & yes & no & yes & 280 & $33 \%$ & $26 \%$ \\
\hline 160 & Savelsbos & yes & no & yes & 360 & $18 \%$ & $15 \%$ \\
\hline 161 & Noorbeemden \& Hoogbos & yes & no & yes & 55 & $55 \%$ & $8 \%$ \\
\hline 162 & Abtskolk \& De Putten & no & yes & no & 500 & $75 \%$ & $17 \%$ \\
\hline 163 & Vlakte van de Raan & yes & no & no & & & \\
\hline 164 & Doggersbank & yes & no & no & & & \\
\hline 165 & Klaverbank & yes & no & no & & & \\
\hline \multirow[t]{3}{*}{166} & Friese Front & no & yes & no & & & \\
\hline & Total & & & & 341616 & $16 \%$ & $8 \%$ \\
\hline & & $\sum_{\substack{\infty \\
m}}^{y}$ & 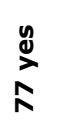 & $\sum_{\substack{\infty \\
1}}^{y}$ & & & \\
\hline
\end{tabular}


Wageningen Environmental Research P.O. Box 47

6700 AA Wageningen

The Netherlands

T +31 (0)317480700

www.wur.nl/environmental-research

Wageningen Environmental Research Report 2880

ISSN 1566-7197
The mission of Wageningen University \& Research is "To explore the potential of nature to improve the quality of life". Under the banner Wageningen University \& Research, Wageningen University and the specialised research institutes of the Wageningen Research Foundation have joined forces in contributing to finding solutions to important questions in the domain of healthy food and living environment. With its roughly 30 branches, 5,000 employees and 10,000 students, Wageningen University \& Research is one of the leading organisations in its domain. The unique Wageningen approach lies in its integrated approach to issues and the collaboration between different disciplines.

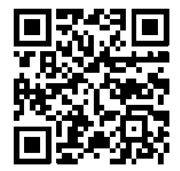





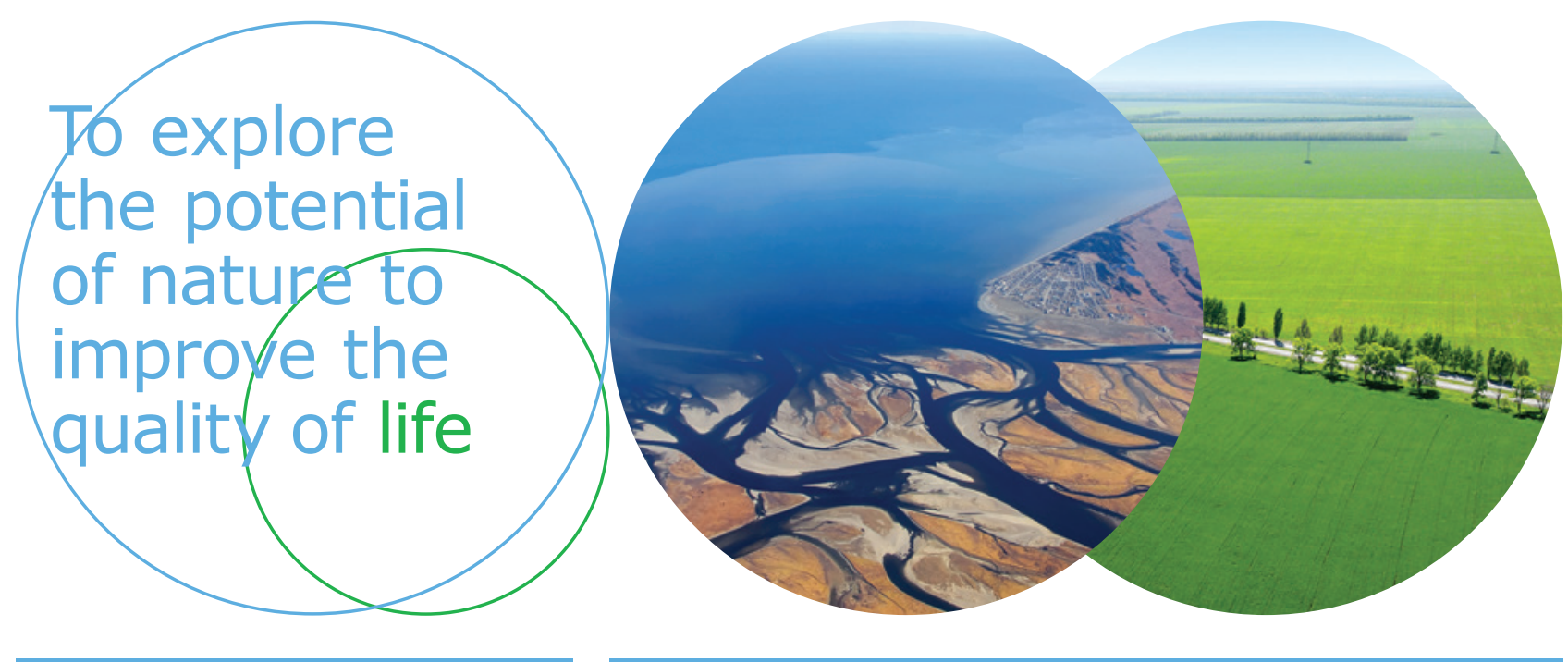

Wageningen Environmental Research P.O. Box 47

$6700 \mathrm{AB}$ Wageningen

The Netherlands

$T+31(0) 317480700$

www.wur.eu/environmental-research

Report 2880

ISSN 1566-7197
The mission of Wageningen University \& Research is "To explore the potential of nature to improve the quality of life". Under the banner Wageningen University \& Research, Wageningen University and the specialised research institutes of the Wageningen Research Foundation have joined forces in contributing to inding solutions to important questions in the domain of healthy food and living environment. With its roughly 30 branches, 5,000 employees and 10,000 students, Wageningen University \& Research is one of the leading organisations in its domain. The unique Wageningen approach lies in its integrated approach to issues and the collaboration between different disciplines. 